\author{
Maksym Potapenko \\ (D) https://orcid.org/0000-0002-0000-8892 \\ Niżyński Uniwersytet Państwowy im. MikoŁaja Gogola
}

\title{
ORMIANIE MOHYLOWA PODOLSKIEGO W ŚWIETLE MATERIAŁÓW V REWIZJI 1795 ROKU
}

Przedstawione poniżej dwa dokumenty dotyczące historii Mohylowa Podolskiego zostały odnalezione w Państwowym Archiwum Obwodu Winnickiego (Дepжавний архів Вінницької області) w zespole 177 pt. „Powiatowa Mohylowsko-Podolska Izba Skarbowa” („Могилів-Подільське повітове казначейство”).

$\mathrm{W}$ zespole tym niemal w całości zachowały się materiały $\mathrm{V}$ rewizji odnośnie do powiatu mohylowskiego w ówczesnym namiestnictwie bracławskim oraz powiatu wierzbowieckiego w namiestnictwie podolskim ${ }^{1}$. Rosyjska administracja skarbowa korzystała z tych materiałów do określenia wymiaru podatkowe$\mathrm{go}^{2}$. Zajmowała się też dalszym uściśleniem ustaleń rewizji. Na to przynajmniej wskazują dwa uzupełnienia do spisu rewizyjnego (skazki rewizyjnej ${ }^{3}$ ) Ormian mohylowskich, opracowane w latach 1798-17994. Po wymazaniu Rzeczypospolitej z mapy Europy tzw. V rewizja była pierwszym obszernym i zestandaryzowanym opisem niemal całej ludności (poza niepłacącą podatków szlachtą posia-

${ }^{1}$ Oba namiestnictwa zostały utworzone na mocy ukazu z 22 maja 1795 roku w miejsce guberni bracławskiej, obejmującej ziemie południowe zaboru rosyjskiego Polski, ale już rok później zostały ponownie scalone w jedną gubernię, noszącą od tej pory nazwę podolskiej.

2 Ю. Легун, О. Петренко, Матеріали ревізійного перепису населення 1795-1796 рр. у фондах Державного архіву Вінницької області, Вінниця 2005, s. 11.

3 Tzw. skazki rewizyjne (Ревизские сказки) były dokumentami obrachunku podatkowego ludności w Cesarstwie Rosyjskim i miały formę imiennych spisów danej grupy społecznej miasta lub wsi, sporządzonych podczas rewizji od pierwszej (1718) do dziesiątej (1858).

4 Державний архів Вінницької області (dalej: ДАВО): ф. 177, оп. 1, спр. 810, арк. 207-208. 
dającą) ziem zabranych przez Cesarstwo Rosyjskie. Jeśli chodzi o Podole, objęła blisko $95 \%$ populacji ${ }^{5}$.

Pierwszy z zamieszczonych tu dokumentów to tabela sumująca wyniki spisów różnych grup ludności Mohylowa Podolskiego. Składa się z dwóch części. W pierwszej została zobrazowana struktura społeczna mieszkańców miasta, w drugiej zaś - zawodowa. Dokument drugi - znacznie obszerniejszy - jest spisem Ormian, którzy razem z Grekami i Żydami byli zaliczani do cudzoziemców. I ten dokument ma formę tabeli. Wstęp informuje o podstawie prawnej (był nią manifest carski z 23 czerwca 1794 roku) i dacie sporządzenia (17 lipca 1795 roku) zestawienia. Podane zostało także nazwisko jego autora - Tadeusza Zielińskiego. Treść informacyjna tabeli została rozdzielona pomiędzy cztery rubryki. W pierwszej wymieniono domostwa (rodziny) i ich mieszkańców, w drugiej - wiek mężczyzn, w trzeciej - wiek kobiet, w czwartej - miejsce pochodzenia i uprawiany przez głowę rodziny zawód. W tabeli opisano kolejno 62 domostwa Ormian osiadłych (,żyjących w domach za kontraktem właściciela”) oraz 18 rodzin „nieosiadłych” (w tym wypadku nie stosowano określenia „dom”), które razem liczyły 271 osób (129 mężczyzn i 142 kobiety). Ta tabela została sporządzona w dwóch wersjach językowych: rosyjskiej i polskiej, co stanowiło normę V rewizji w nowej (porozbiorowej) części cesarstwa, przy czym polska wersja dokumentu powstała później. Jest też spójniejsza pod względem językowym, ale posiada skróty i ślady redagowania. W czwartej rubryce polskiej wersji tabeli zdarzają się zapisy, które przeczą informacjom $\mathrm{w}$ analogicznej do niej rubryce wersji rosyjskiej (na przykład zapisy o domostwach nr 26, 28 i 41). Polski pisarz tabeli nie odnotował wiernie wielu nazwisk, zarówno ustalonych (na przykład domostwa $\mathrm{nr} 25$, 29 , 44), jak i nowo utworzonych od imienia ojcowskiego, tj. typu patronimicznego (na przykład domostwa nr 20-23). Oprócz tego polska wersja dokumentu nie została ukończona, bo znajdujemy liczne opuszczenia w czwartej rubryce, szczególnie jeśli chodzi o rodziny nieosiadłe.

Porównanie obu drukowanych poniżej dokumentów daje podstawę do stwierdzenia, że Ormianie nie stanowili w Mohylowie Podolskim grupy licznej w ogóle mieszkańców miasta (5,8\%). Mimo to byli wpływowi w sferze ekonomicznej, zwłaszcza w handlu hurtowym (9 z 15 domostw, czyli 60\%) oraz wytwarzania safianu (co najmniej 15 domostw z 19, czyli 79\%). Dokumenty te świadczą też o radykalnej zmianie w strukturze lokalnej społeczności ormiańskiej u schyłku XVIII wieku. Z „handlowej” przeobraziła się ona w „safianniczą”. Ogółem w wytwórczość safianów na różny sposób (właściciele, majstrzy, robotnicy, sprzedawcy, oficjaliści) zaangażowanych było co najmniej 30 domostw Ormian osiadłych. Niewykluczone, że przynajmniej część z 14 robotników nieosiadłych także pracowała w tym obszarze. Wynika z tego, że większość społeczności ormiańskiej była silnie powiązana między sobą stosunkami producenckimi.

5 Ю. Легун, О. Петренко, Матеріали ревізійного перепису, s. 10. 
Przyczyną zmiany profilu zawodowego Ormian było zmniejszenie roli miasta w obrocie handlowym. Do lat osiemdziesiątych XVIII wieku było ono ważnym ośrodkiem handlu tranzytowego między Polską, Rosją i Turcją. Wraz z utrwaleniem się władzy rosyjskiej na wybrzeżach Morza Czarnego rola dawnych lądowych szlaków handlowych stopniowo wygasała. Handel Mohylowa ucierpiał także z powodu powodzi w latach 1780 i 1785, pożaru w 1784 roku oraz dżumy w 1787 roku$^{6}$. Wreszcie wejście Mohylowa w skład Cesarstwa Rosyjskiego w 1793 roku postawiło miejscowe kupiectwo przed problemem przystosowania się do nowych warunków (zmiana granic i komór celnych, objęcie przepisami rosyjskiej polityki celnej). Największym ciosem było ograniczenie handlu z imperium osmańskim ${ }^{7}$. W rezultacie Mohylów przekształcił się z ośrodka handlu tranzytowego w punkt handlu przygranicznego, przeważnie kontrabandy, która coraz bardziej koncentrowała się w rękach Żydów ${ }^{8}$.

Wszystko to stało się podstawą jakościowej aktualizacji ormiańskiej wspólnoty. Większość z 44 ormiańskich gospodarstw domowych (rody Kramarów, Horodelskich, Tabaczników, Stambulskich, Zadyków, Mintianów, Kupiłów i innych), figurujących w inwentarzu Mohylowa z 1772 roku, porzuciło miasto w ciągu kolejnych dwudziestu paru lat ${ }^{9}$. Znamienne, że w skazce rewizyjnej z 1795 roku tylko odnośnie do jednego gospodarstwa domowego wpisano „rodem z samego miasta Mohylowa" (nr 19, rodzina Grzegorza Piaseckiego). Absolutną większość właścicieli domostw stanowili przesiedleńcy w pierwszym pokoleniu. Geografia ich pochodzenia była niezwykle rozległa, ale dominowali przybysze z Galicji, czyli z zaboru austriackiego - co najmniej 30 osiadłych i 14 nieosiadłych gospodarstw domowych. Świadectwem ich niedostatecznej integracji z miejscowym społeczeństwem było praktykowanie etnicznej kooperacji w zakresie rzemiosła i zawieranie małżeństw monoetnicznych (endogamia).

Dokumenty 3 i 4 mają charakter brudnopisów, ale zostały dołączone do edycji dla pełności obrazu danych uzyskanych w $\mathrm{V}$ rewizji.

Publikowane dokumenty pozwalają także zweryfikować wiarygodność cytowanego już opisu powiatu mohylowskiego, którego fragment opublikował Walerij Diaczok ${ }^{10}$. Anonimowy autor opisu zaniżył liczbę Ormian do 20 rodzin (53 mężczyzn i 62 kobiet) ${ }^{11}$. Stało się to dlatego, że miał on do swej dyspozycji

${ }^{6}$ В. Дячок, Маловідомі джерела про розселення вірмен у Подільській губернії кіния ХVIII століття, w: Актуальні питання вірменознавства, 3/4, Вінниця 2016, s. 37; Центральний державний історичний архів України у м. Київ (dalej: ЦДІАУК): ф. 486, оп. 3, спр. 335, арк. 1463в.

7 В. Дячок, Маловідомі джерела, s. 36.

8 Военно-статистическое обозрение Российской империи. Подольская губерния, 10/2, Санкт-Петербург 1849, s. 128.

9 ЦДІАУК: ф. 49, оп. 1, спр. 1855, арк. 5зв.

10 В. Дячок, Маловідомі джерела, s. 34-38.

${ }^{11}$ Ibidem, s. 37. 
nie pełne materiały rewizji 1795 roku, a tylko drugą część tabeli sumującej (zob. dokument 1). Zaliczył do Ormian wszystkie rodziny właścicieli przedsiębiorstw safianniczych - 20 rodzin składających się z 53 mężczyzn i 72 kobiet (w spisie pomyłkowo - 62) $)^{12}$. Przy tym autor opisu kierował się przekonaniem, że Ormianie monopolizowali w Mohylowie wytwórczość safianu. $Z$ tego względu znaczną liczbę przedsiębiorstw safianniczych scalił w jedną „garbarnię”, która „przynależy Ormianom"13.

Podsumowując, trzeba stwierdzić, że publikowane poniżej dokumenty zawierają cenne dane genealogiczne o Ormianach mohylowskich. Są też ważnym źródłem dla badań historyczno-demograficznych, ponieważ oddają pełny skład tej społeczności wraz z dosyć rozmaitymi i porównywalnymi charakterystykami społecznymi.

Zachowany został język oryginału wraz z ortografią i językowo-stylistycznymi osobliwościami.

12 ДАВО: ф. 177, оп. 1, спр. 810, арк. 21зв.

13 В. Дячок, Маловідомі джерела, s. 35. 


\section{Dokument 1}

Перечневая ведомость

$1795^{\text {го }}$ году июля $17^{\text {го }}$ дня

\section{Перечневая ведомость}

Изъ влеченная изъ ревижскихъ сказокъ и ведомостей города Могилева в числе семействъ и жителей по состояниямъ с означениемъ в чемъ они упражняются

\begin{tabular}{|c|c|c|c|c|}
\hline & \multirow{2}{*}{$\begin{array}{c}\text { Число } \\
\text { семейств }\end{array}$} & \multicolumn{2}{|c|}{ Число душъ } \\
\hline & & & Мужеска & Женска \\
\hline \multicolumn{5}{|l|}{ Духовенство } \\
\hline \multicolumn{2}{|l|}{ Монашествующихъ } & & 2 & \\
\hline \multicolumn{2}{|l|}{ Светскихъ } & & 7 & 7 \\
\hline \multicolumn{2}{|c|}{ Церковнослужителей } & & 11 & 2 \\
\hline \multicolumn{5}{|c|}{ Шляхетства } \\
\hline \multicolumn{2}{|l|}{ Живущихъ домами } & 13 & 36 & 25 \\
\hline \multicolumn{2}{|c|}{ Неимеющихъ домовъ } & & 16 & 12 \\
\hline \multicolumn{5}{|c|}{ Иностранных входящих в перепись } \\
\hline \multirow{3}{*}{ Грековъ } & Гильдейскихъ & 30 & 125 & 83 \\
\hline & Оседлыхъ мещанскихъ & 87 & 148 & 163 \\
\hline & Неоседлыхъ & & 23 & 26 \\
\hline \multirow{4}{*}{ Армянъ } & Гильдейскихъ & 5 & 16 & 12 \\
\hline & Неоседлыхъ & & 2 & \\
\hline & Оседлыхъ мещанскихъ & 57 & 96 & 102 \\
\hline & Неоседлыхъ & & 15 & 28 \\
\hline \multirow{4}{*}{ Евреевъ } & Гильдейскихъ & 39 & 165 & 140 \\
\hline & Неоседлыхъ & & 2 & 3 \\
\hline & Оседлыхъ мещанскихъ & 360 & 575 & 602 \\
\hline & Неоседлыхъ & & 134 & 153 \\
\hline \multicolumn{5}{|c|}{ Коренныхъ поселянъ } \\
\hline $\begin{array}{l}\text { Христианъ } \\
\text { владельческихъ }\end{array}$ & Оседлыхъ & 383 & 842 & 818 \\
\hline $\begin{array}{l}\text { Принадлежащихъ } \\
\text { духовенству }\end{array}$ & Оседлыхъ & 25 & 52 & 55 \\
\hline \multicolumn{5}{|c|}{ Входящихъ в перепись } \\
\hline $\begin{array}{l}\text { Зашедшихъ изъ } \\
\text { другихъ державъ }\end{array}$ & Оседлыхъ & 14 & 28 & 30 \\
\hline \multirow{2}{*}{ Цыганъ } & Оседлых & 24 & 46 & 47 \\
\hline & Неоседлыхъ & & 5 & 4 \\
\hline \multicolumn{2}{|l|}{ Итого } & 1036 & 2346 & 2302 \\
\hline \multicolumn{5}{|c|}{ Из того числа } \\
\hline \multicolumn{2}{|c|}{ Отправляющій гуртовой торгъ } & 15 & 51 & 36 \\
\hline \multicolumn{2}{|c|}{ Лавочной торгъ } & 50 & 172 & 144 \\
\hline \multicolumn{2}{|c|}{ Разной мелочной торгъ } & 85 & 192 & 182 \\
\hline \multicolumn{2}{|c|}{ Торгующих горячимъ виномъ и протчими напитками } & 92 & 205 & 207 \\
\hline \multicolumn{2}{|c|}{ Живущихъ разнымъ промысломъ } & 168 & 336 & 358 \\
\hline \multicolumn{2}{|c|}{ Промысляющихъ извозомъ } & 1 & 2 & 1 \\
\hline \multicolumn{2}{|c|}{ Ремесленниковъ } & & & \\
\hline
\end{tabular}




\begin{tabular}{|l|c|c|c|}
\hline \multicolumn{4}{|c|}{ Перечневая ведомость } \\
Изъ влеченная изъ ревижскихъ сказокъ и ведомостей города Могилева в числе \\
семействъ и жителей по состояниямъ с означениемъ в чемъ они упражняются \\
\hline & Число & \multicolumn{1}{|c|}{ Число душъ } \\
\cline { 2 - 4 } & семейств & Мужеска & Женска \\
\hline Часовыхъ мастеровъ & 1 & 3 & 1 \\
\hline Золотарей & 1 & 2 & 1 \\
\hline Серебрянниковъ & 3 & 11 & 8 \\
\hline Слесарей & 2 & 4 & 2 \\
\hline Портныхъ & 50 & 98 & 99 \\
\hline Хлебниковъ & 3 & 2 & 6 \\
\hline Сапожниковъ & 93 & 210 & 195 \\
\hline Месниковъ & 3 & 11 & 16 \\
\hline Кузнецовъ & 22 & 50 & 42 \\
\hline Авчинниковъ & 29 & 69 & 58 \\
\hline Коноваловъ & 1 & 1 & 1 \\
\hline Медниковъ & 1 & 3 & 2 \\
\hline Алавенишниковъ & 2 & 4 & 6 \\
\hline Рымаровъ & 2 & 4 & 7 \\
\hline Позументщиковъ & 3 & 8 & 5 \\
\hline Ткачей & 14 & 29 & 32 \\
\hline Гаршешниковъ & 10 & 20 & 22 \\
\hline Бондаровъ & 17 & 38 & 24 \\
\hline Каменщиковъ & 8 & 13 & 20 \\
\hline Столяровъ & 2 & 2 & 3 \\
\hline Плотниковъ & 7 & 16 & 13 \\
\hline Гребешниковъ & 2 & 4 & 4 \\
\hline Фабрикантовъ сафиянныхъ & 19 & 37 & 29 \\
\hline Работниковъ сафиянныхъ & 20 & 53 & 72 \\
\hline Цырюлниковъ & 16 & 12 & 21 \\
\hline Музыкантовъ & 2 & 3 & 5 \\
\hline Шапошниковъ & 167 & 386 & 381 \\
\hline Садовниковъ & 103 & 192 & 233 \\
\hline Хлебопашцевъ & & \\
\hline В черной работе и работникахъ & 26 & 24 \\
\hline
\end{tabular}

Подпорутчикъ Федоръ Шараповъ

(ДАВО: ф. 177, оп. 1, спр. 810, арк. 20-21 зв.) 


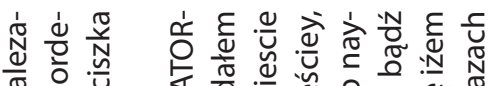
可 해

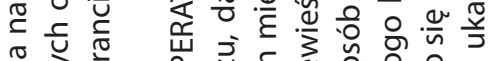

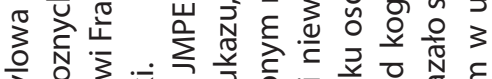

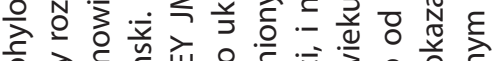

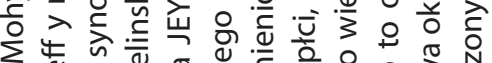
苟 N

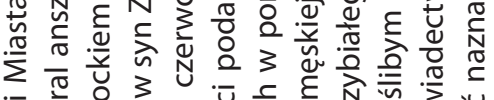
:= ช

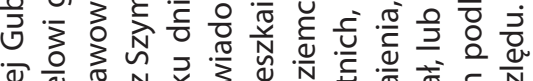

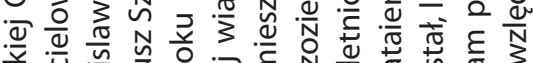
药 는

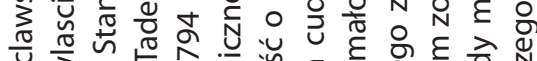

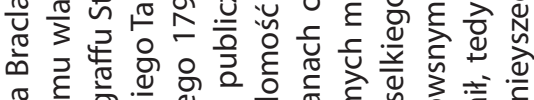

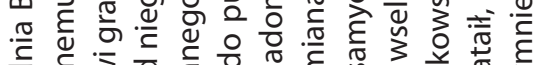

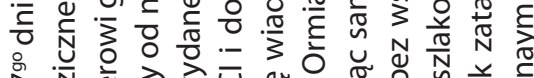

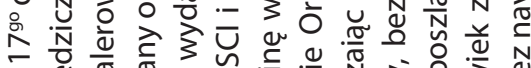

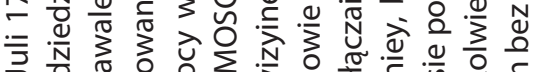

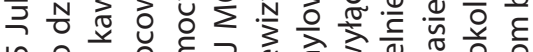

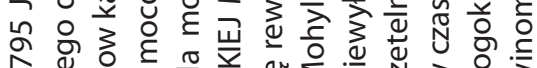

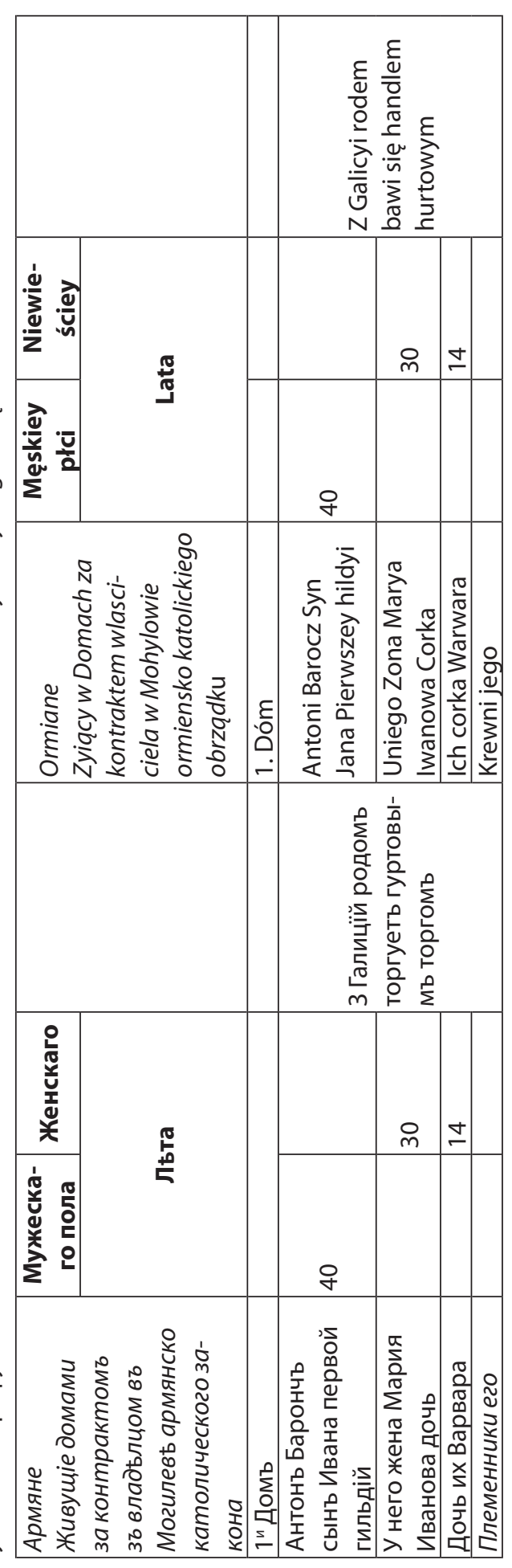

芯

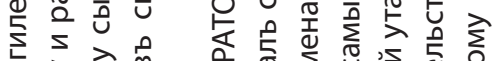

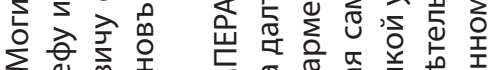

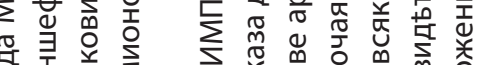

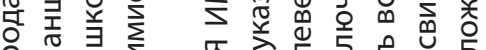
은 :

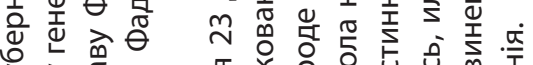

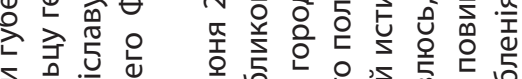

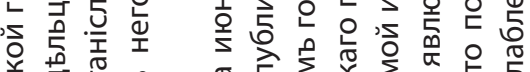

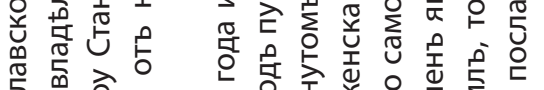
5 क 䒛

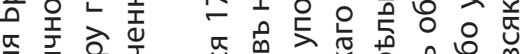

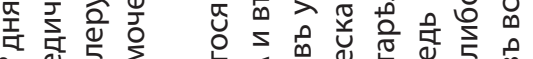
过 $\sum_{0}$ $\therefore$ 。

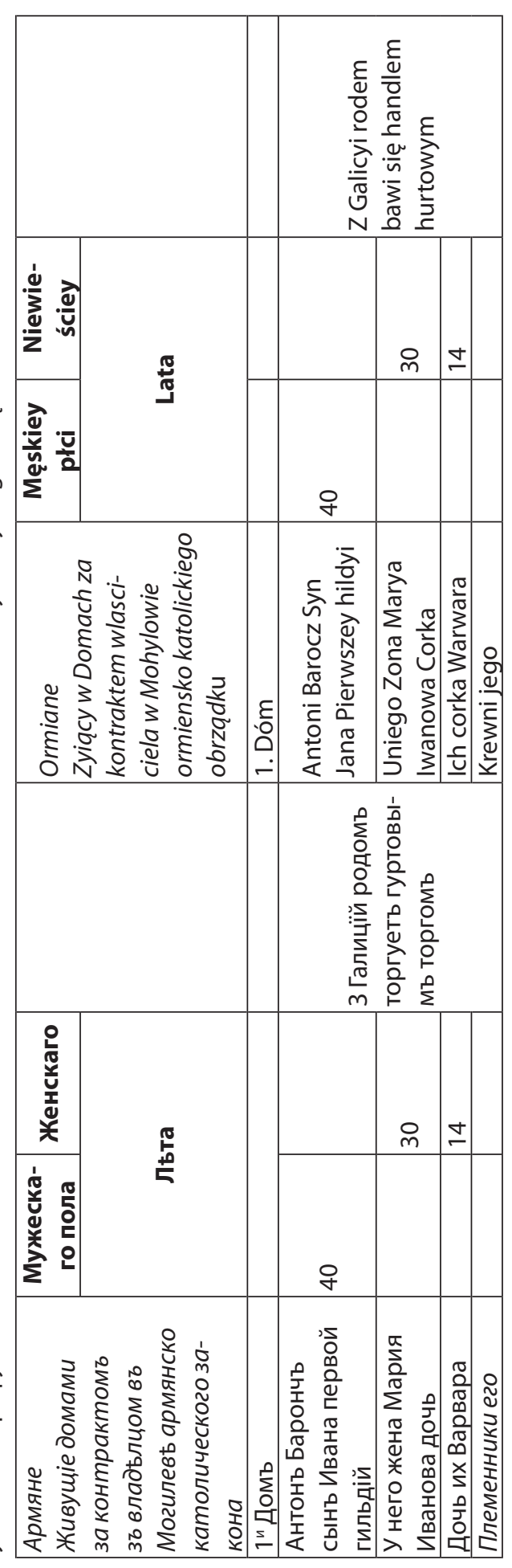

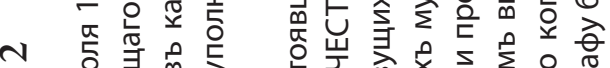

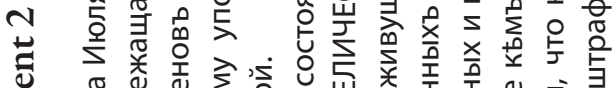

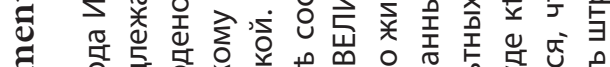

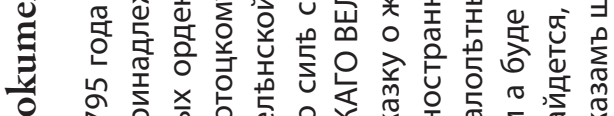

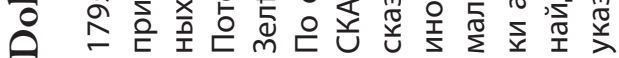




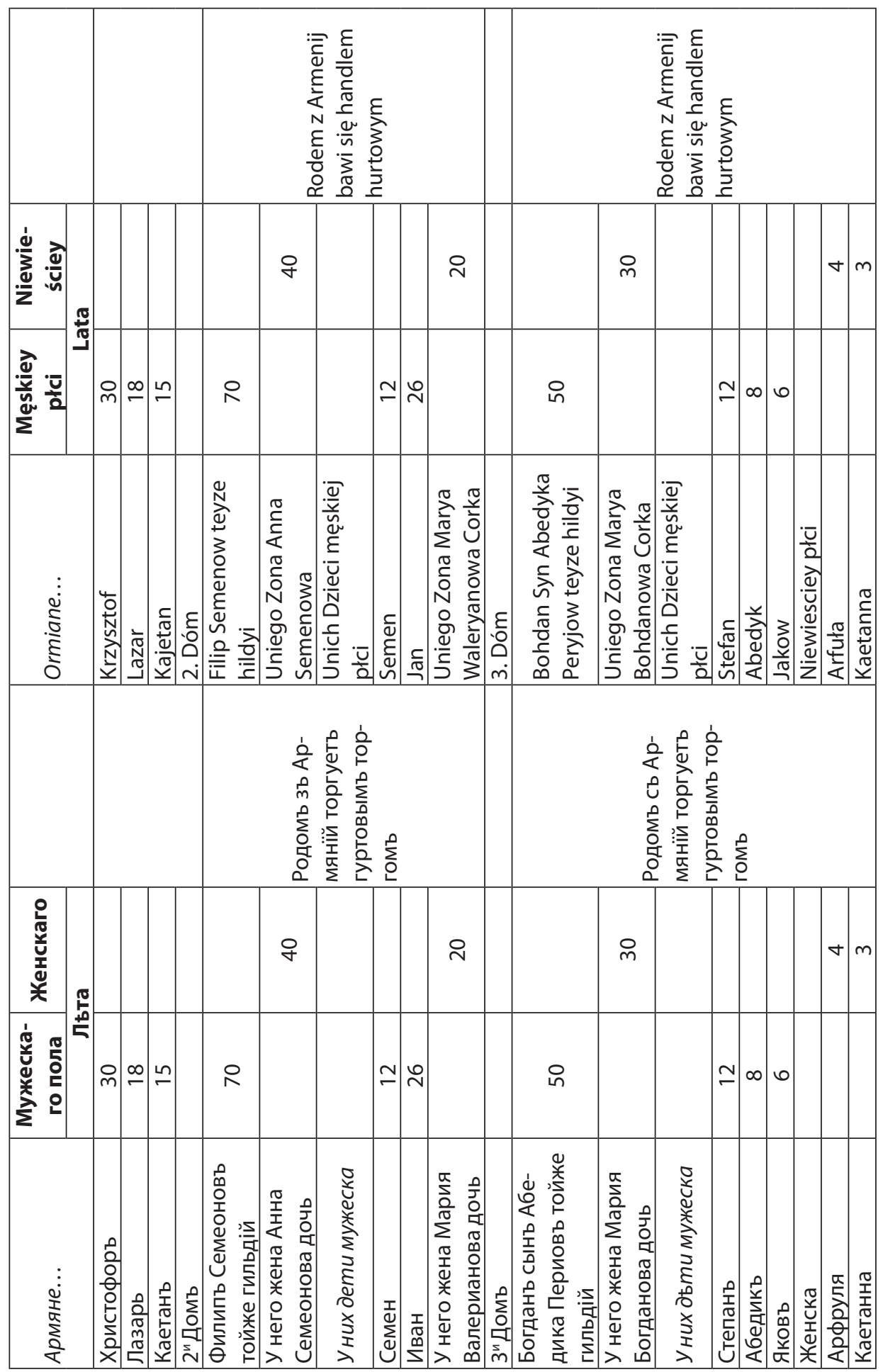




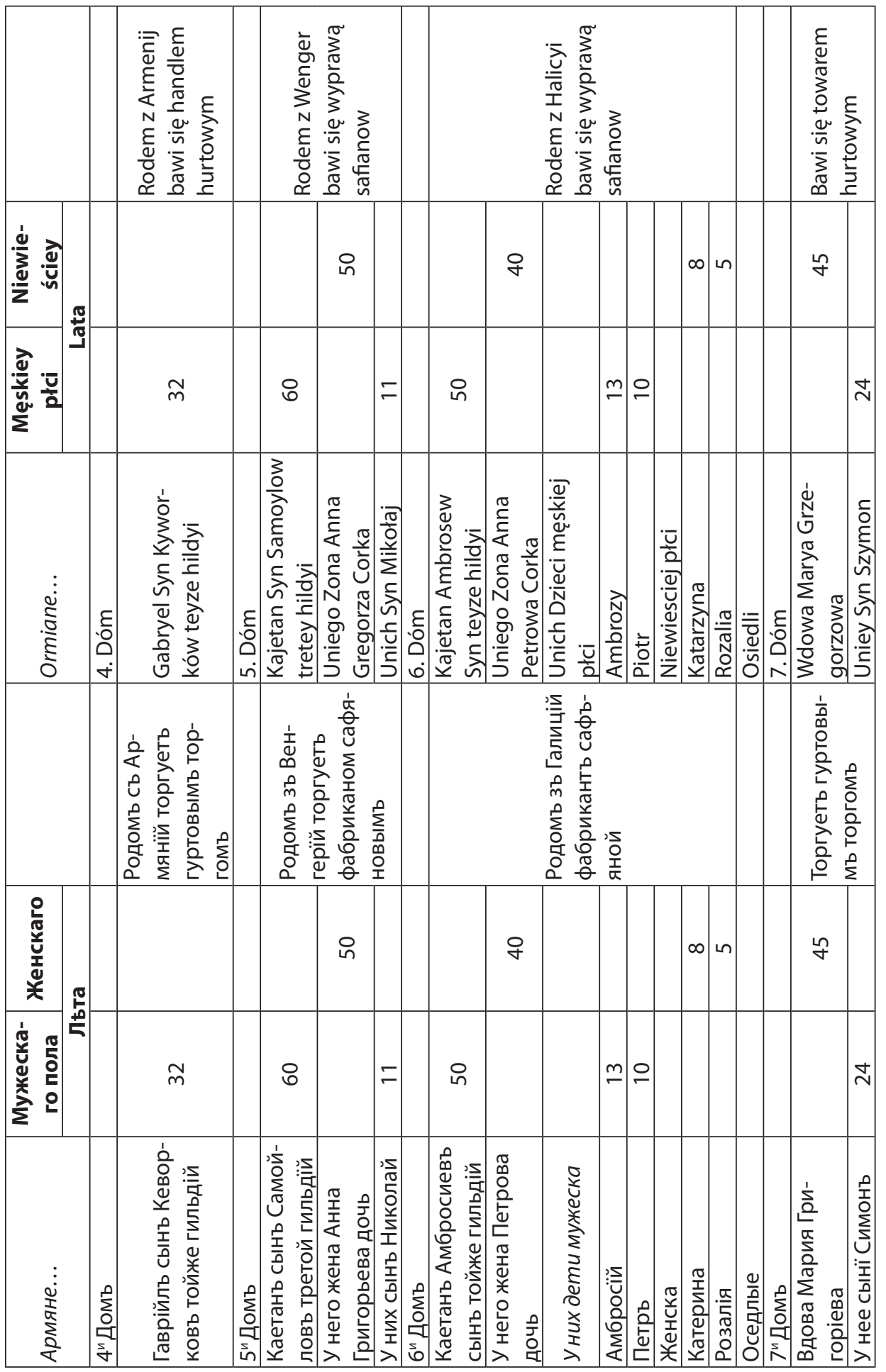




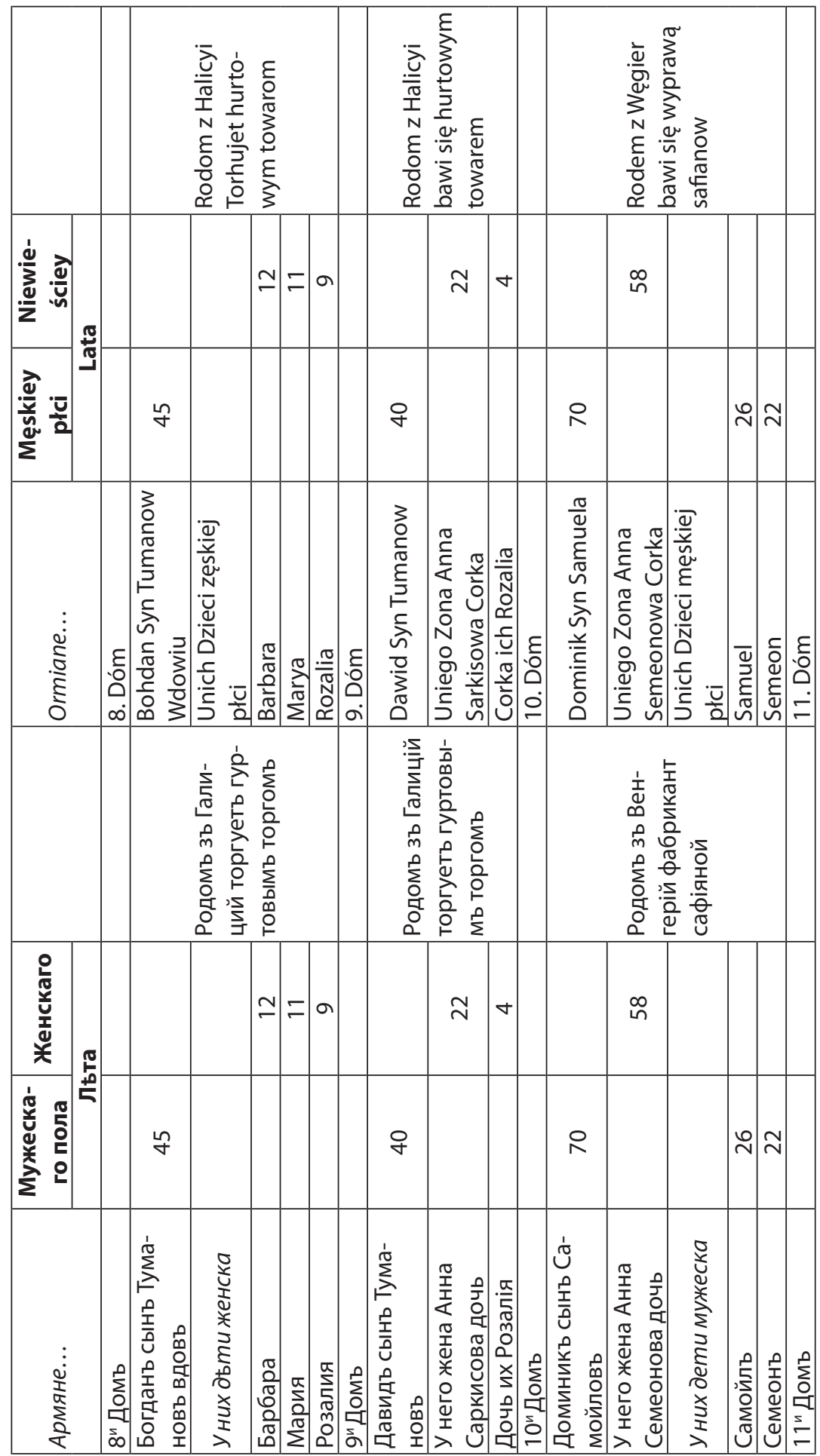




\begin{tabular}{|c|c|c|c|c|c|c|c|c|c|c|c|c|c|c|c|c|c|c|c|c|c|}
\hline & & & है & $\begin{array}{l}\sum_{0}^{\infty} \\
\frac{\pi}{0} \\
\sum_{0}^{0} \\
0 \\
0 \\
0\end{array}$ & & & & & & & & 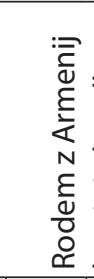 & 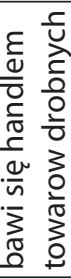 & & & & & & 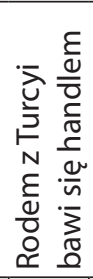 & $\begin{array}{l}3 \\
0 \\
\frac{3}{0} \\
3 \\
0 \\
+ \\
\frac{1}{0} \\
\widehat{c} \\
0 \\
0 \\
\frac{0}{0}\end{array}$ & \\
\hline $\begin{array}{ll}\frac{\omega}{z} & \frac{\partial}{U} \\
\frac{\omega}{z} & \cdot\end{array}$ & $\$$ & & 우 & & 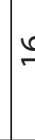 & & & & $\infty$ & & & ㅇ & & & & $\ln$ & & & $\stackrel{\mathrm{m}}{\mathrm{m}}$ & & \\
\hline$\frac{\frac{\partial}{y}}{\underline{y}} \frac{\bar{u}}{0}$ & & 유 & & & & & & & & & రి & & & $m$ & & & & ㅇํ & & & ר \\
\hline $\begin{array}{l}\vdots \\
\stackrel{\vdots}{\vdots} \\
\frac{\delta}{\delta} \\
\vdots\end{array}$ & & 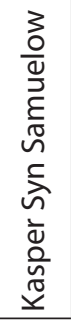 & 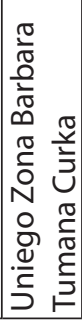 & 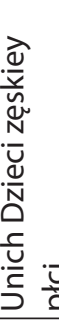 & 2) & & & & & & 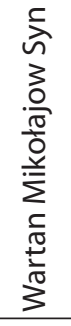 & 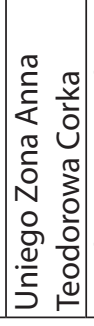 & 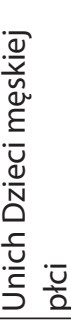 & .0 & 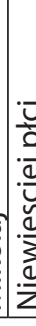 & $\left.\right|^{2}$ & 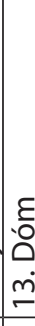 & 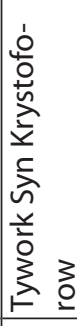 & 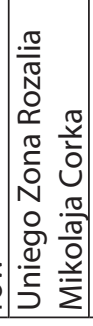 & 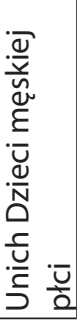 & 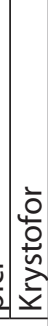 \\
\hline & & & s & 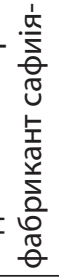 & & & & & & & & 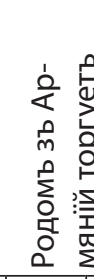 & 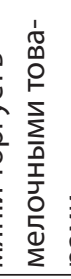 & & & & & & 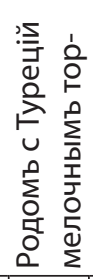 & 은 & \\
\hline 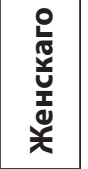 & 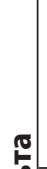 & & 우 & & 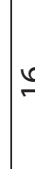 & & & & $\infty$ & & & $\stackrel{\mathrm{m}}{ }$ & & & & in & & & ㅇ & & \\
\hline 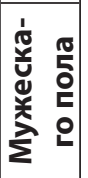 & 흐 & 은 & & & & & & & & & 으 & & & $m$ & & & & 은 & & & থ \\
\hline 递 & & 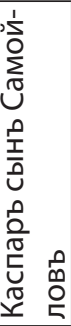 & 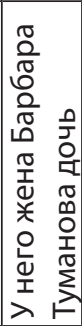 & 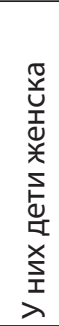 & 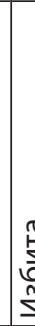 & & & & & $\sum_{0}^{0}$ & 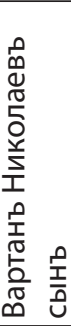 & 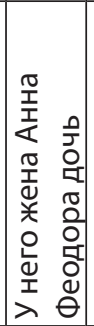 & 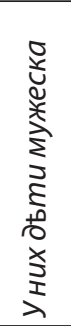 & 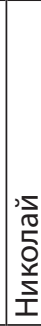 & 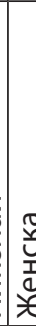 & 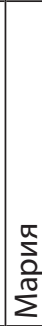 & 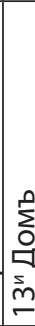 & 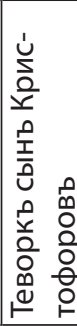 & 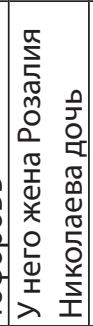 & 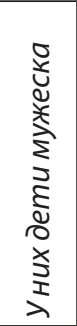 & 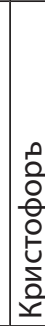 \\
\hline
\end{tabular}




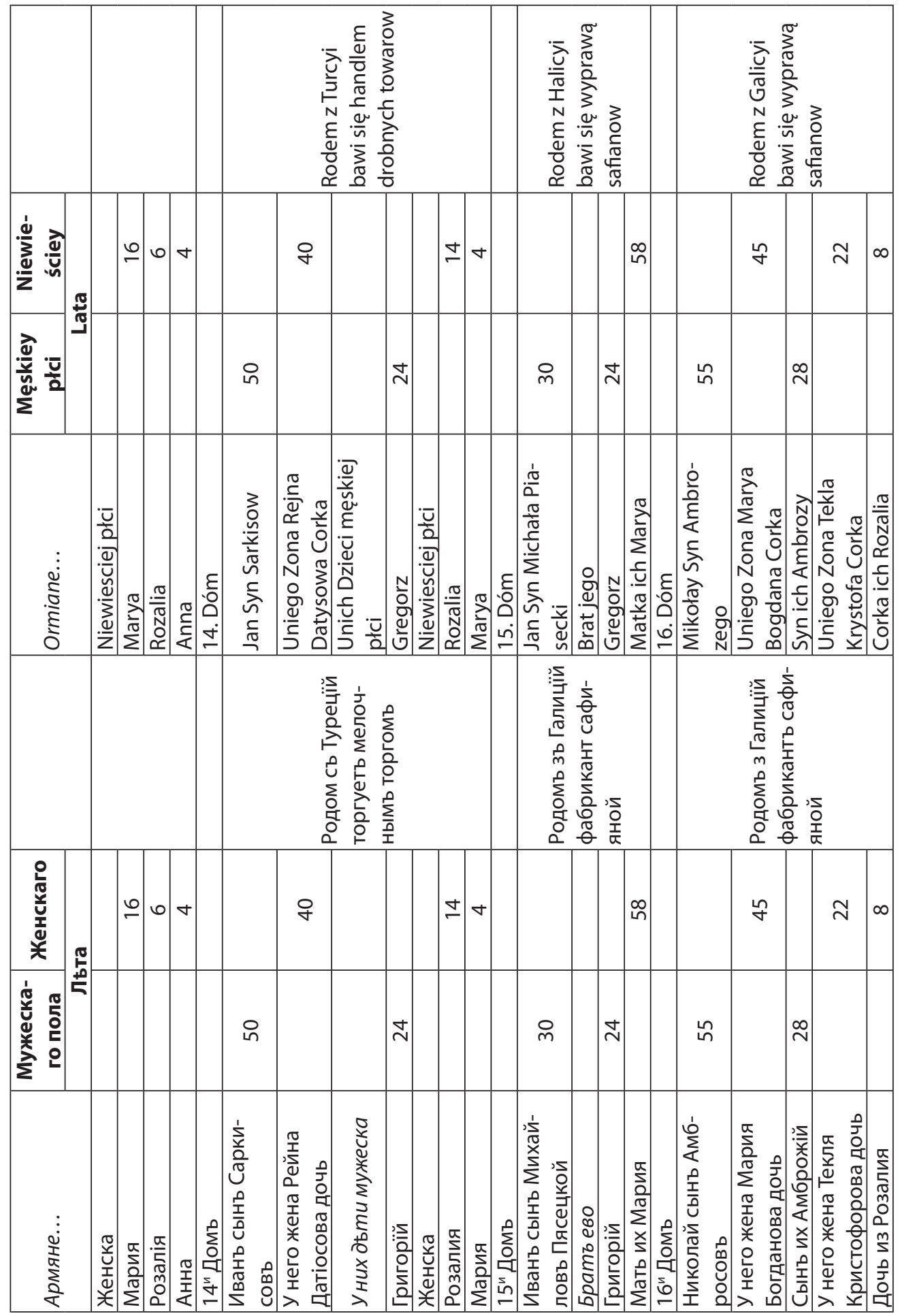




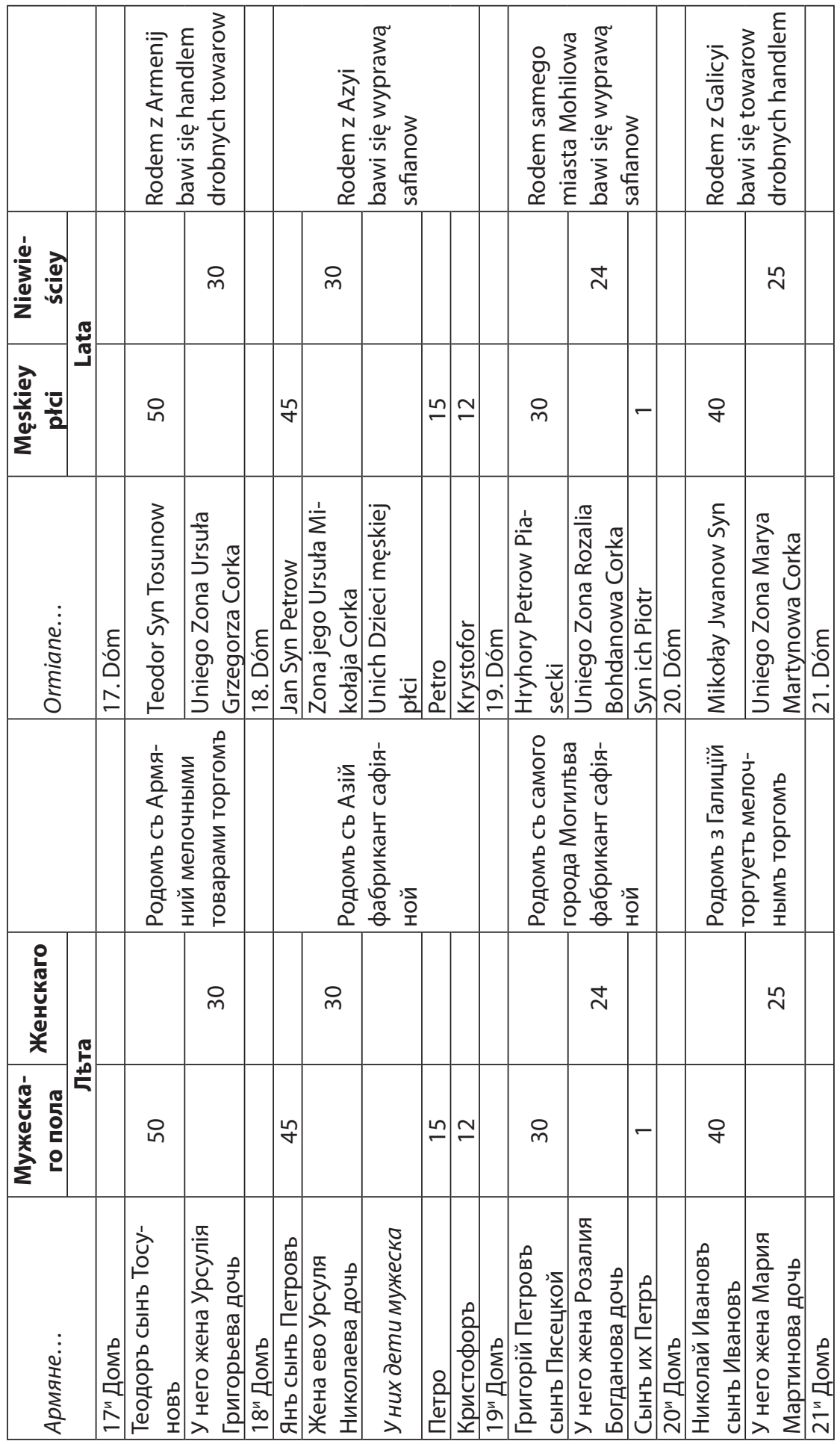




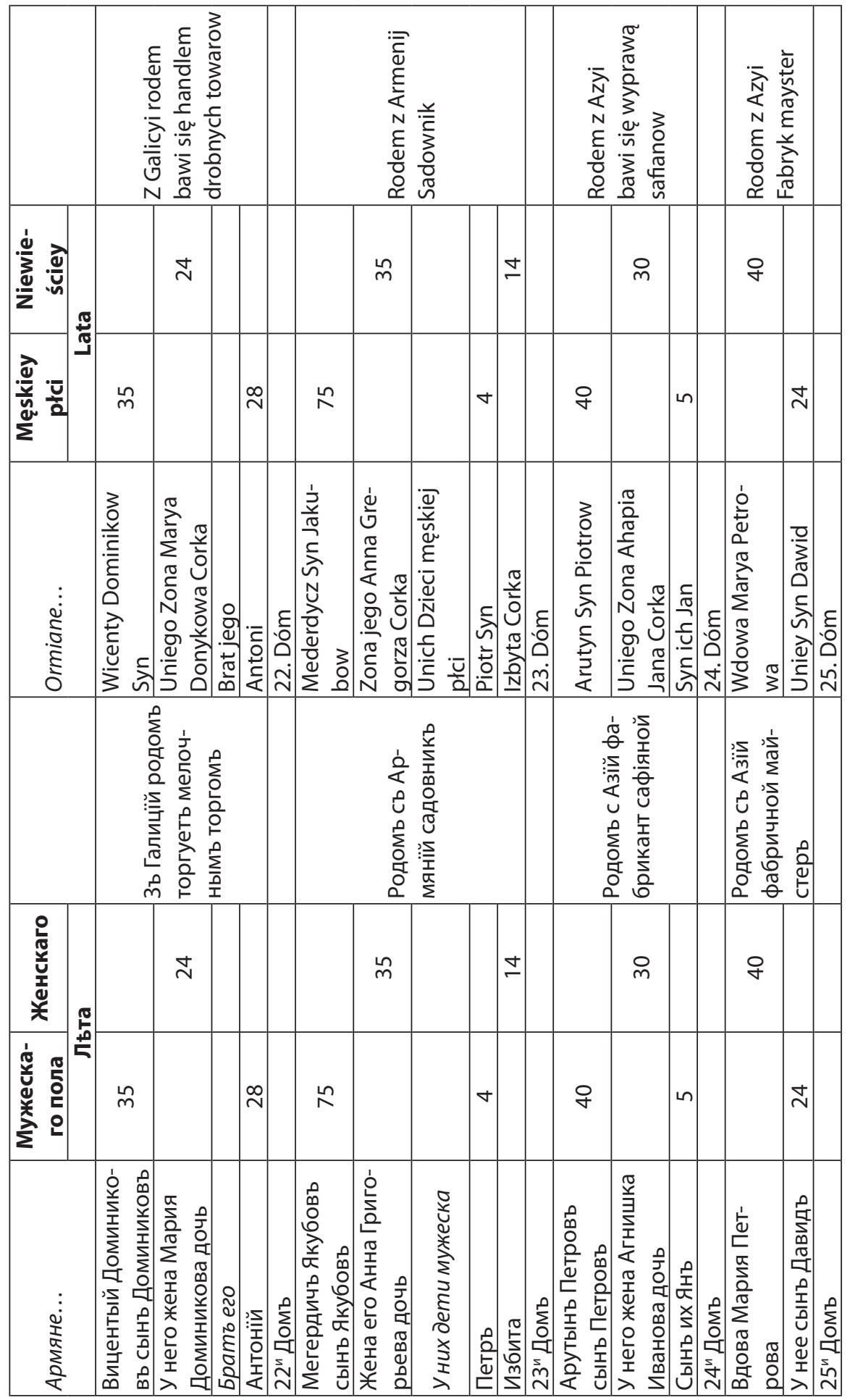




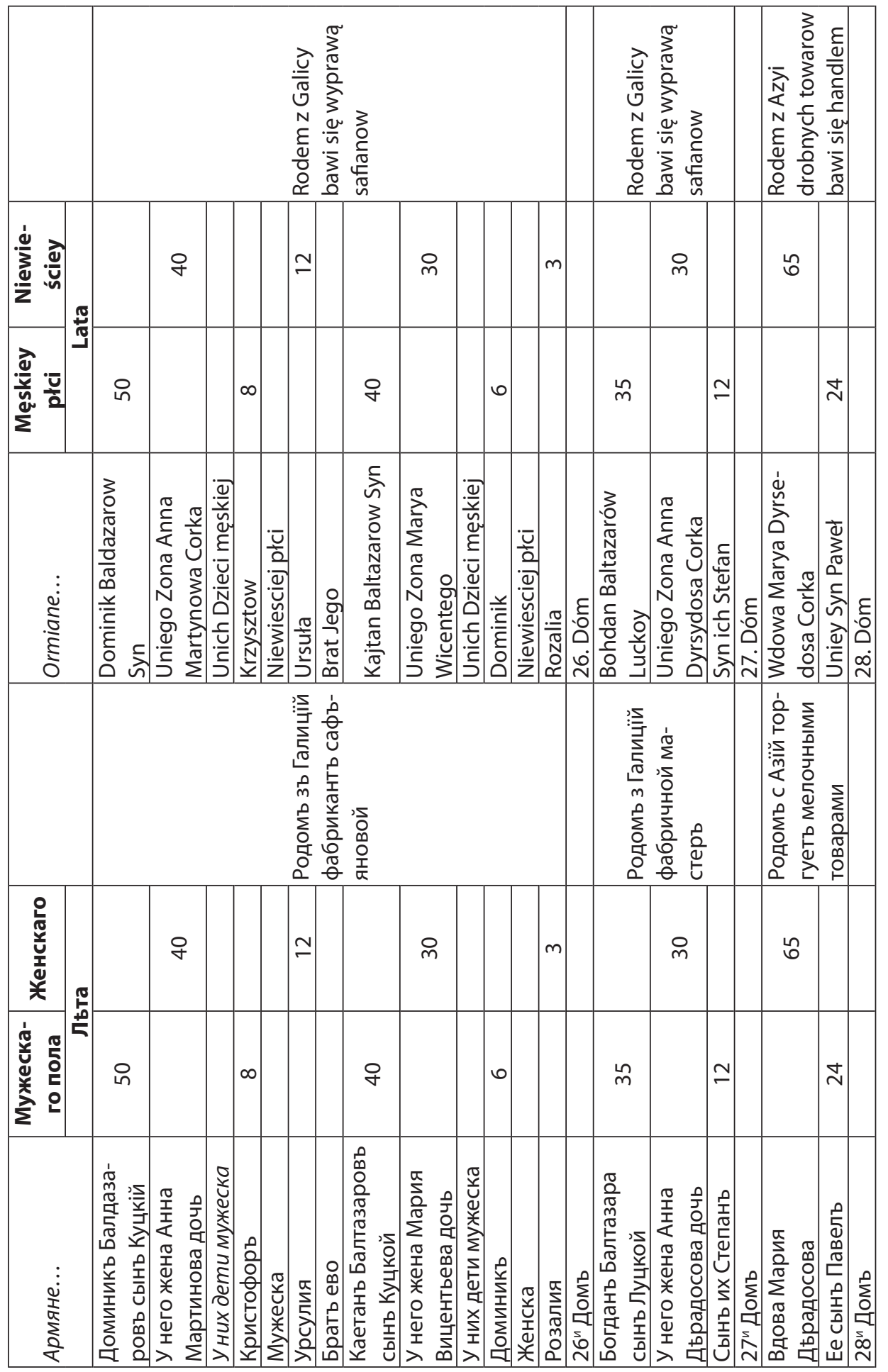




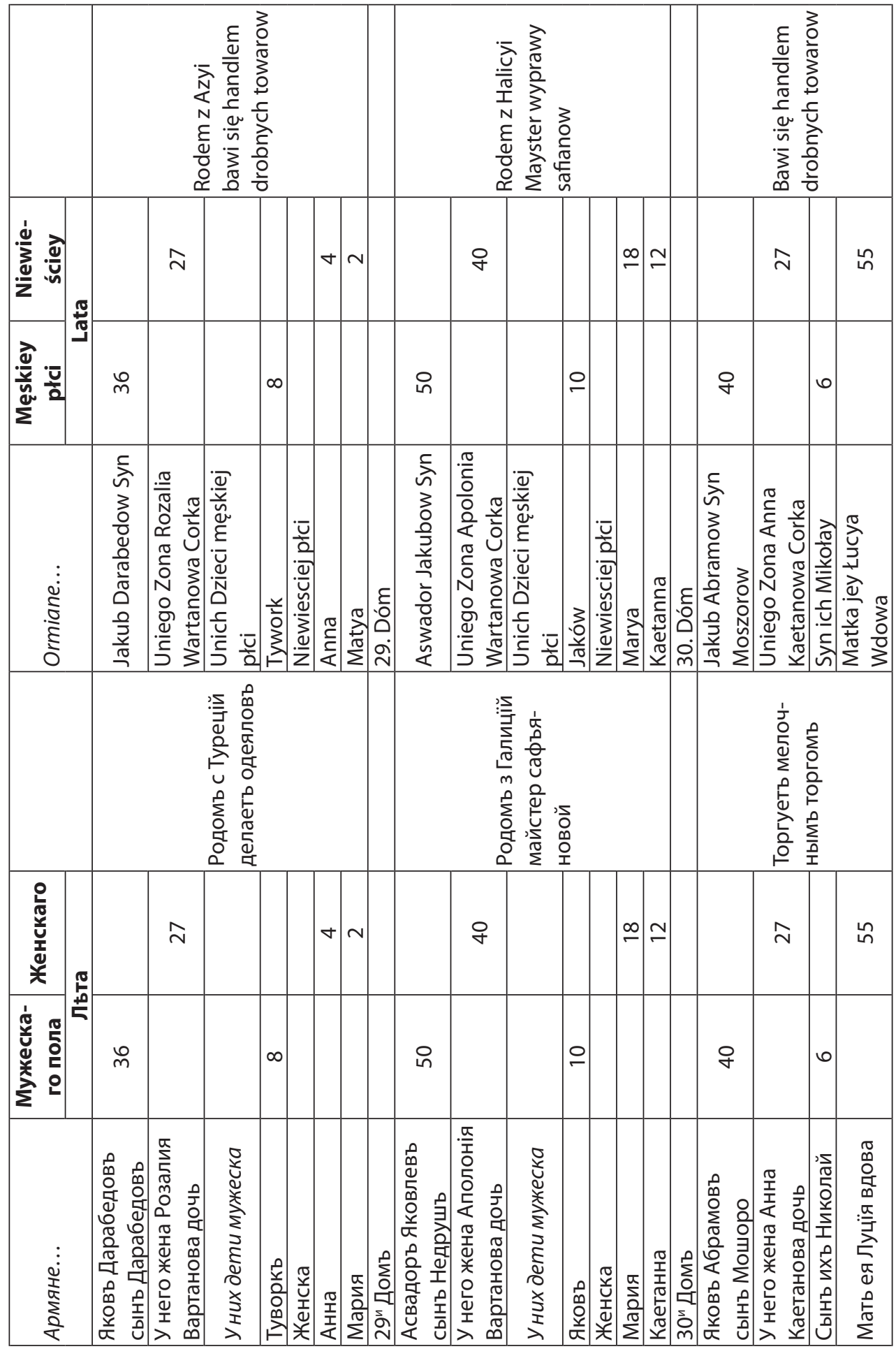




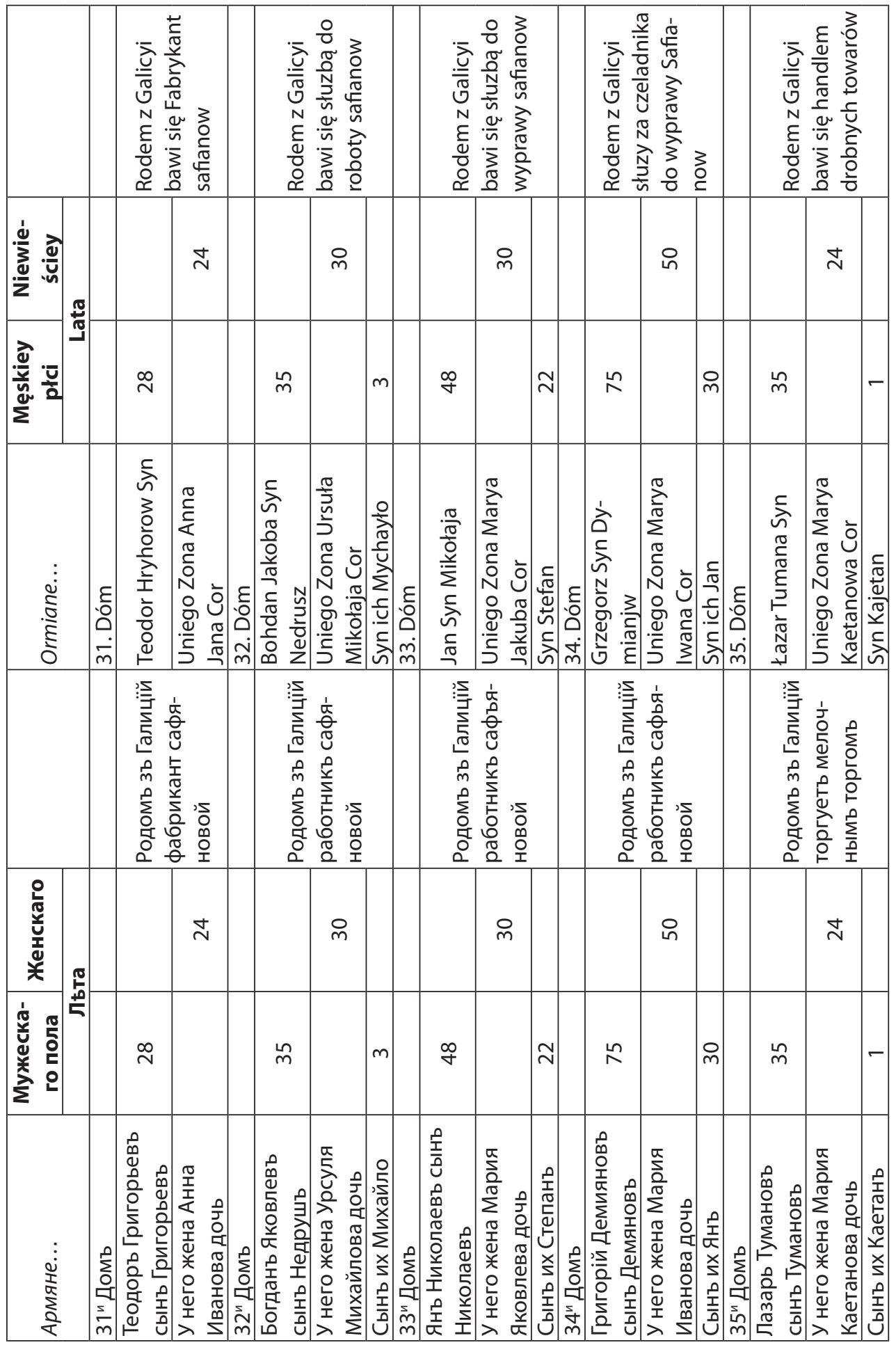




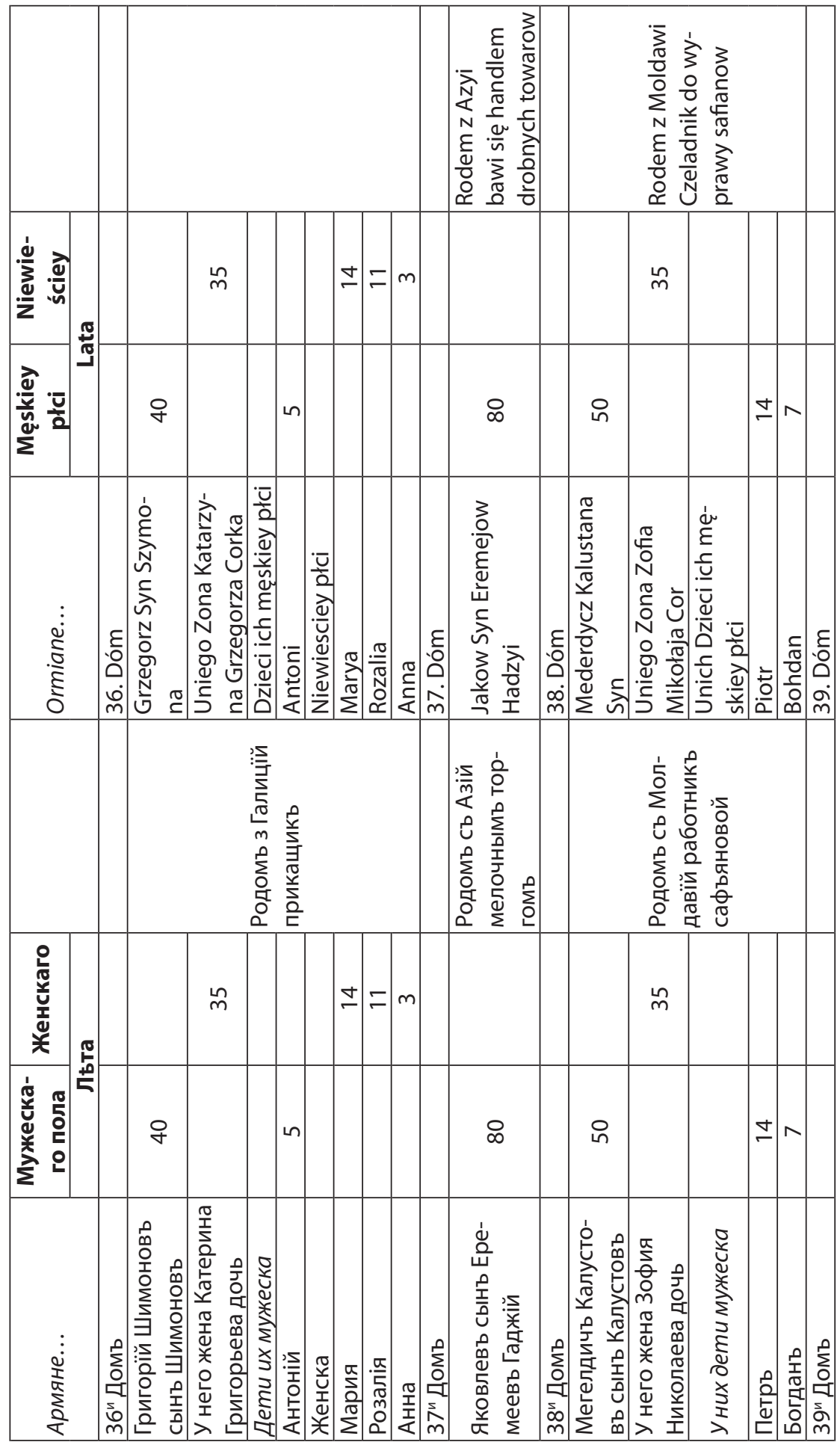




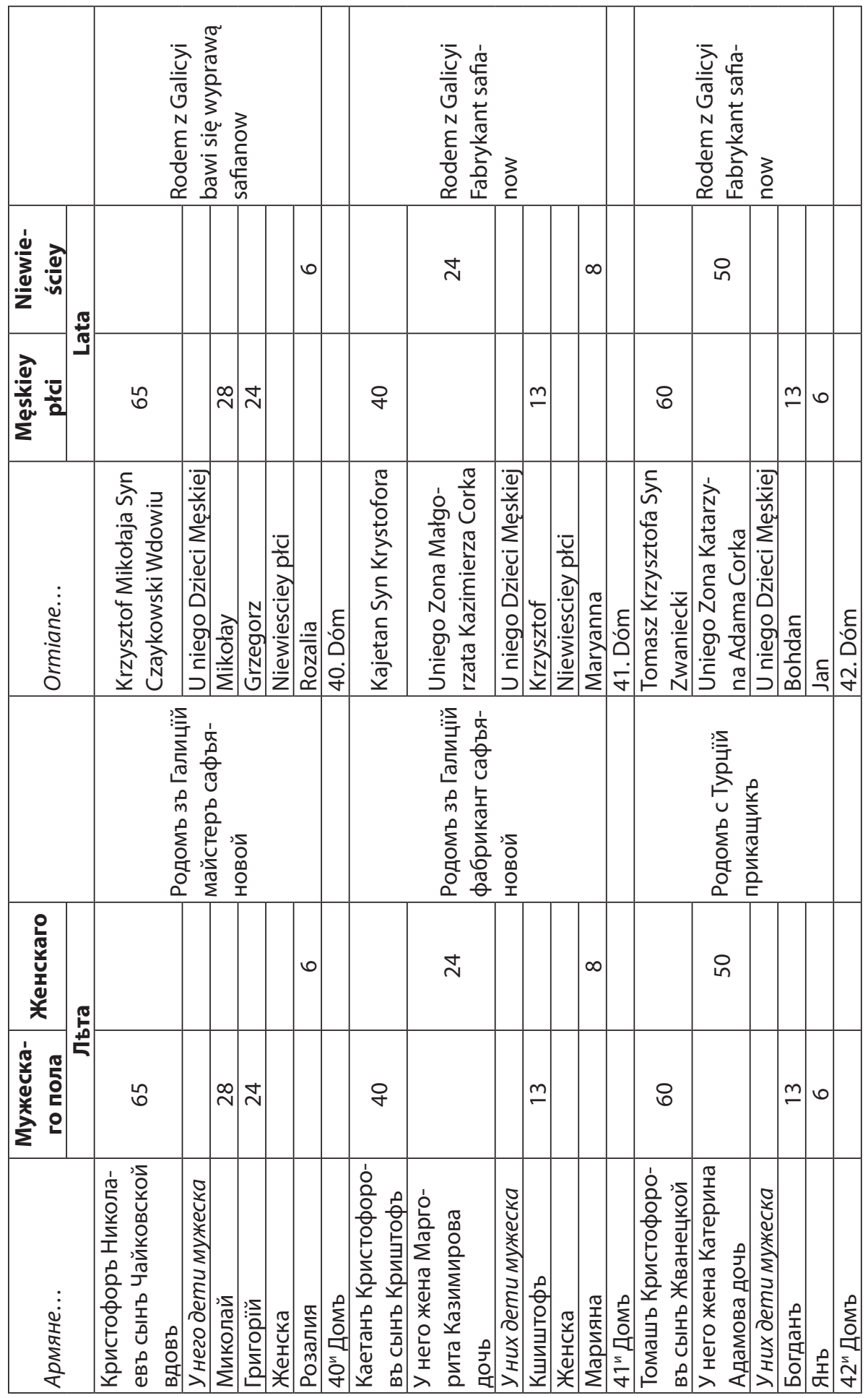




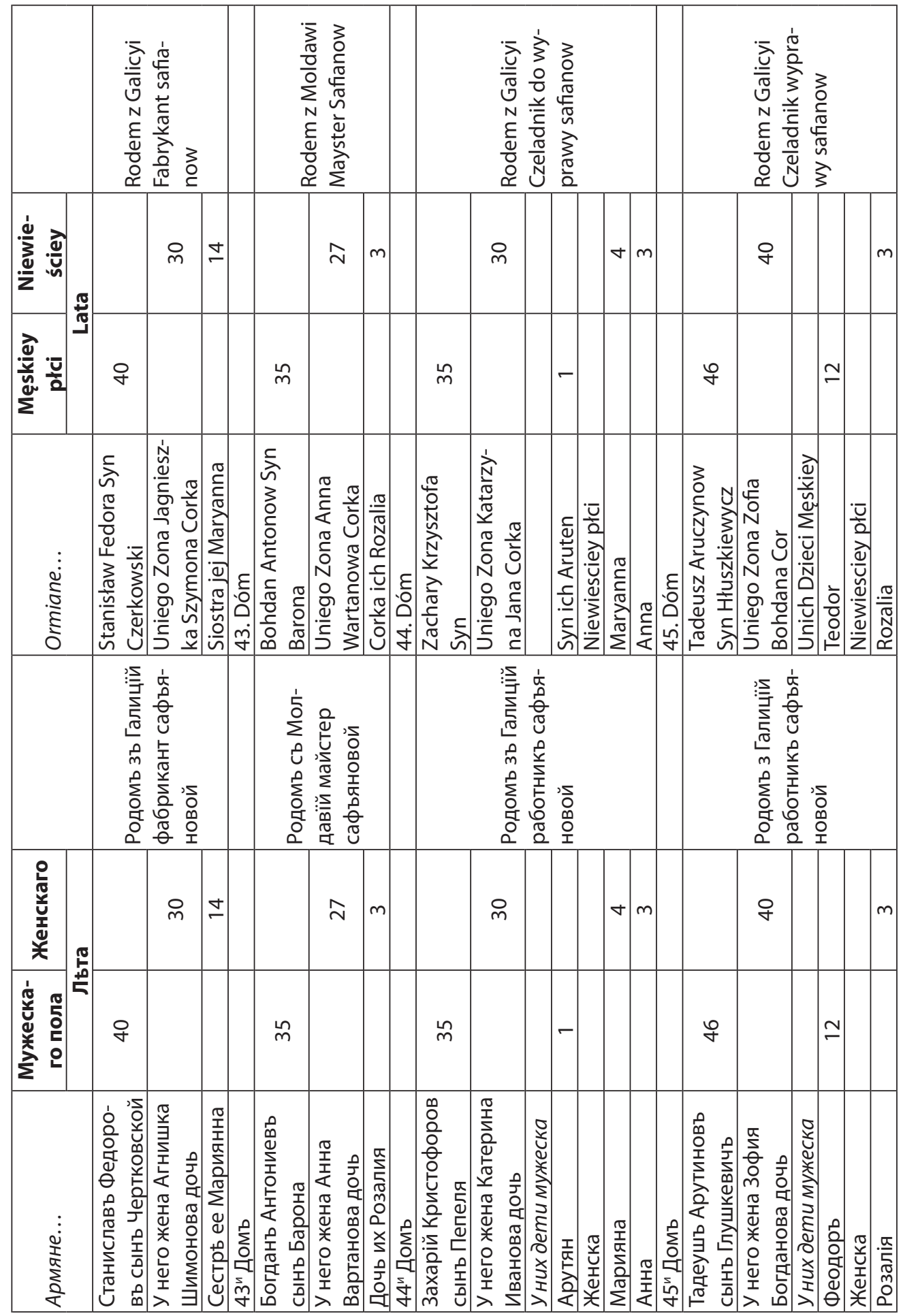




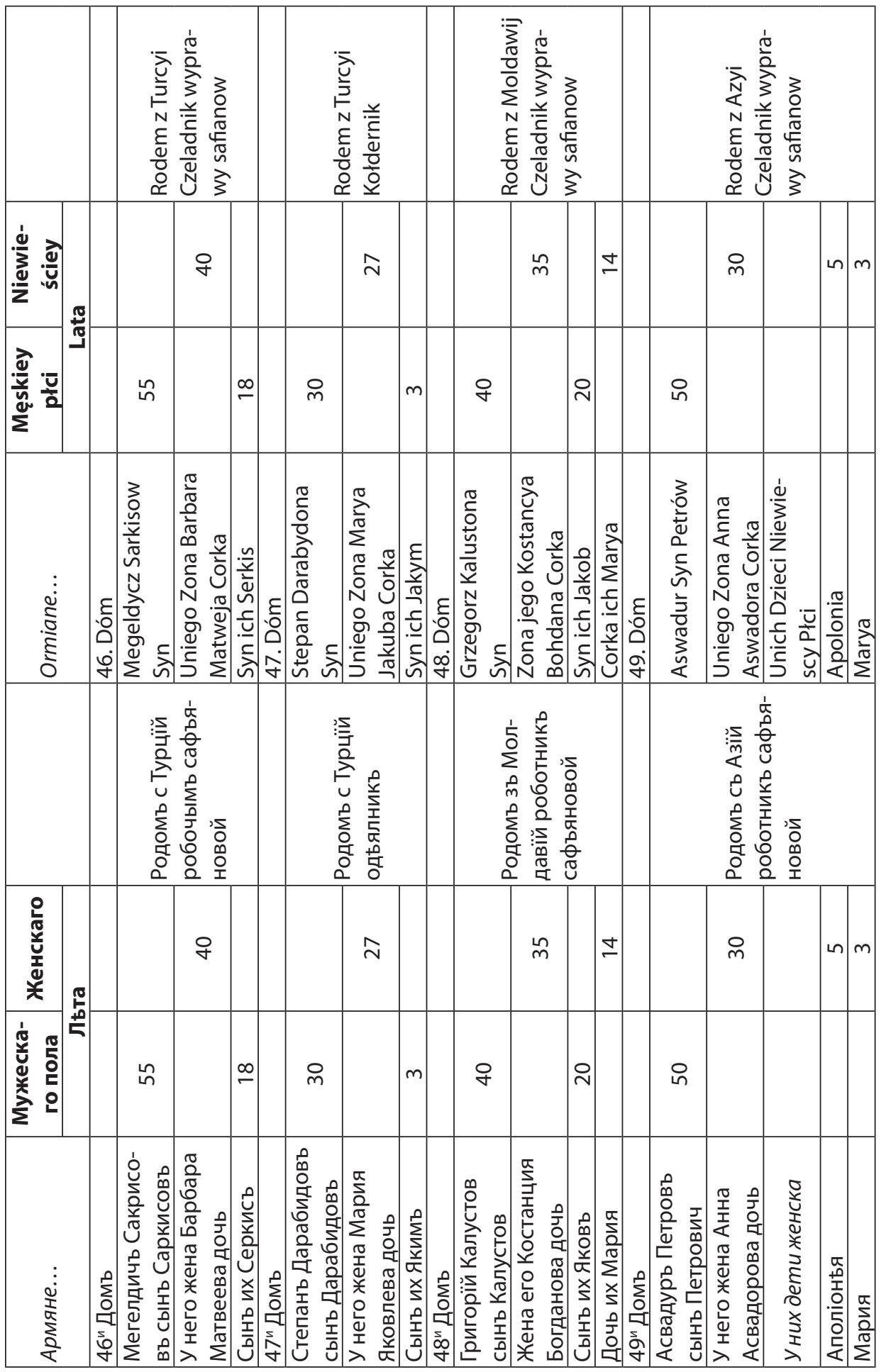




\begin{tabular}{|c|c|c|c|c|c|c|c|c|c|c|c|c|c|c|c|c|c|c|c|c|}
\hline & & & 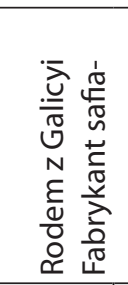 & & & 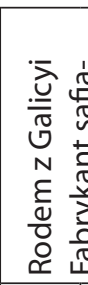 & $\begin{array}{l}1 \\
0 \\
0 \\
0 \\
0 \\
0 \\
\vdots \\
\vdots \\
2 \\
0 \\
0 \\
0 \\
0 \\
0\end{array}$ & & & & & & & & & & & 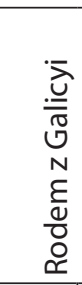 & 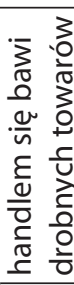 & \\
\hline$\frac{0}{z} \frac{d}{z}$ & 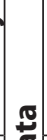 & & & $\stackrel{\llcorner}{\sim}$ & & & $\stackrel{\text { m }}{ }$ & & & $\underset{\sim}{ \pm}$ & & & & $\forall$ & $m$ & $N$ & & & 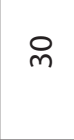 & $r$ \\
\hline 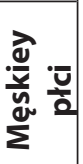 & & & $\stackrel{\llcorner}{m}$ & & & $\stackrel{\llcorner}{m}$ & & & 이 & & & 6 & & & & & & $\stackrel{1}{m}$ & & \\
\hline 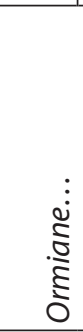 & & 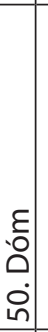 & 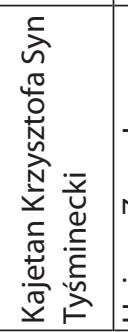 & 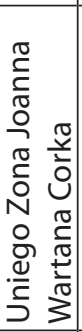 & 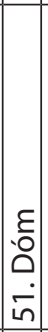 & 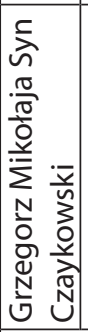 & 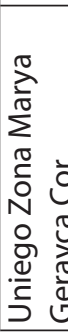 & 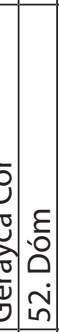 & 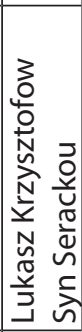 & 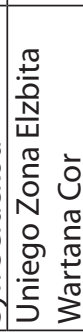 & 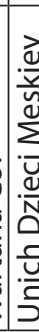 & 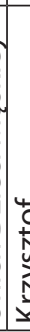 & 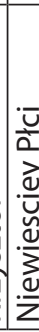 & | & 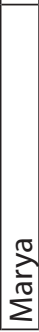 & 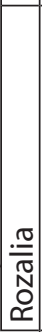 & 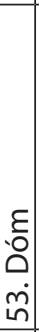 & 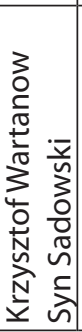 & 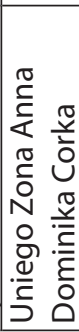 & 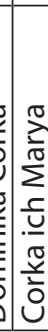 \\
\hline & & & 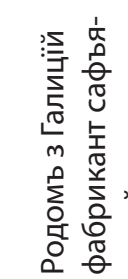 & 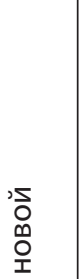 & & 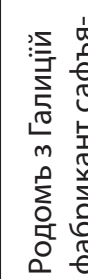 & 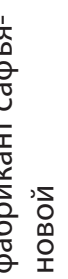 & & & & 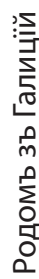 & & & & & & & 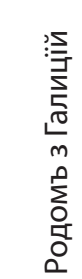 & 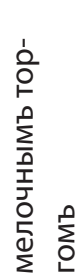 & \\
\hline 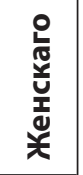 & $\mathbb{\sigma}$ & & & $\stackrel{\llcorner}{\sim}$ & & & ○ & & & $\stackrel{\searrow}{\sim}$ & & & & $\checkmark$ & $m$ & $N$ & & & 이 & 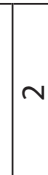 \\
\hline 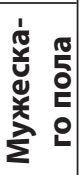 & & & $\stackrel{i n}{m}$ & & & $\stackrel{\sim}{m}$ & & & ○ & & & 6 & & & & & & $\stackrel{\Perp n}{m}$ & & \\
\hline 这 & & 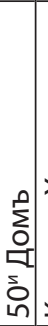 & 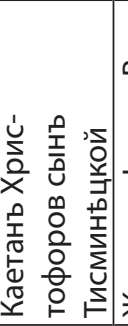 & 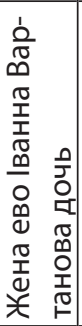 & $\begin{array}{l}1 \\
\vdots \\
0 \\
0 \\
5 \\
\text { s } \\
\text { in } \\
\end{array}$ & 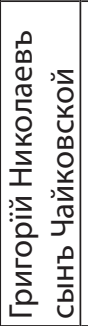 & 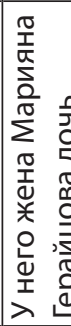 & 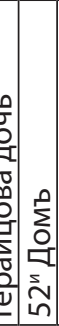 & 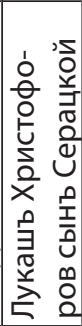 & 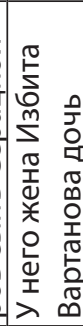 & 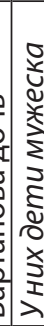 & 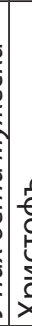 & 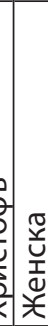 & $\stackrel{0}{I}$ & $\begin{array}{l}\frac{\pi}{\sigma} \\
\frac{0}{\sigma}\end{array}$ & 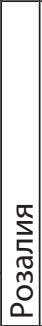 & 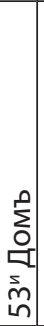 & 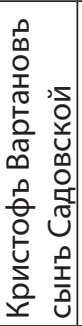 & 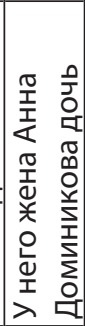 & 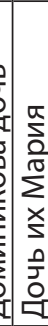 \\
\hline
\end{tabular}




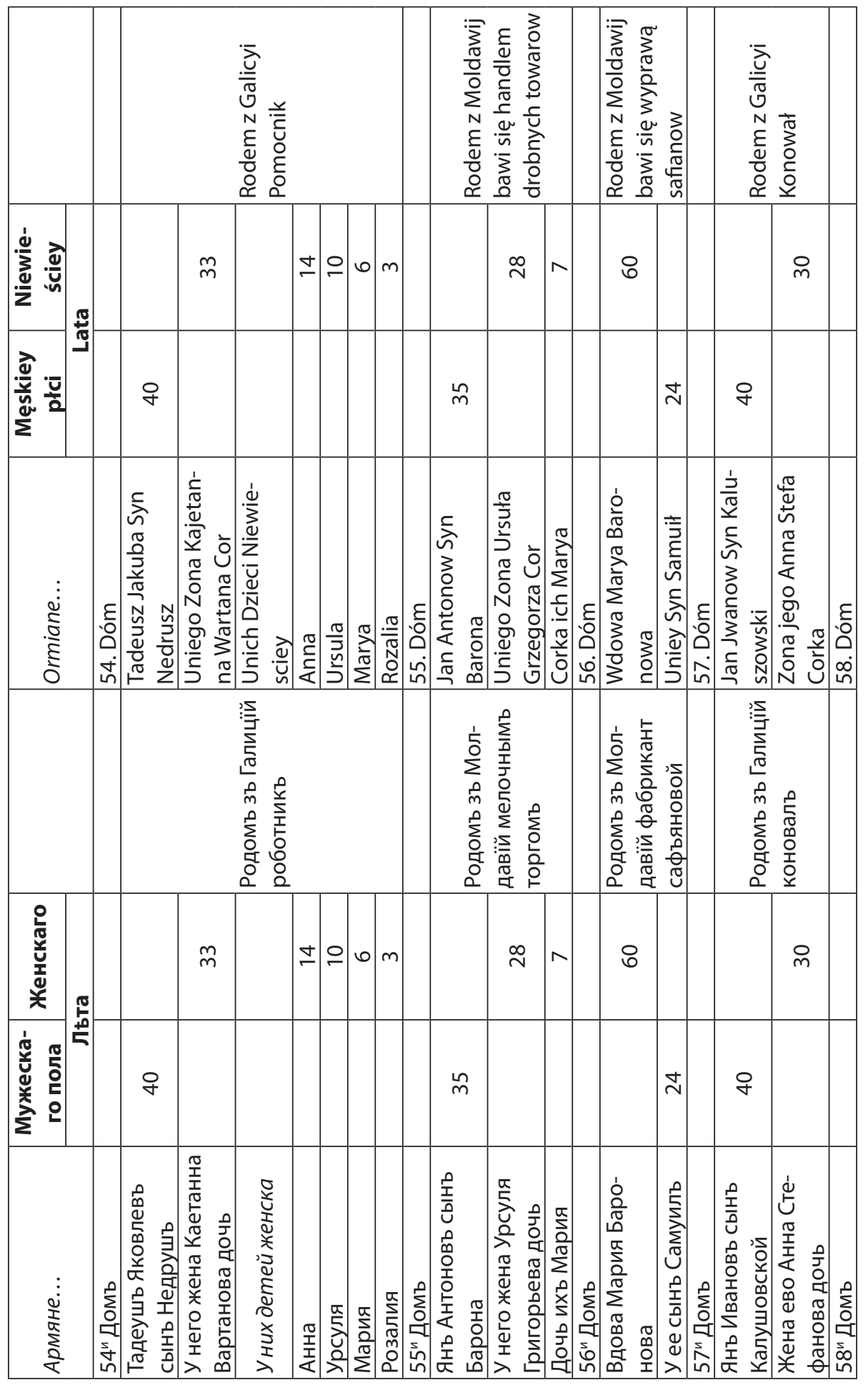




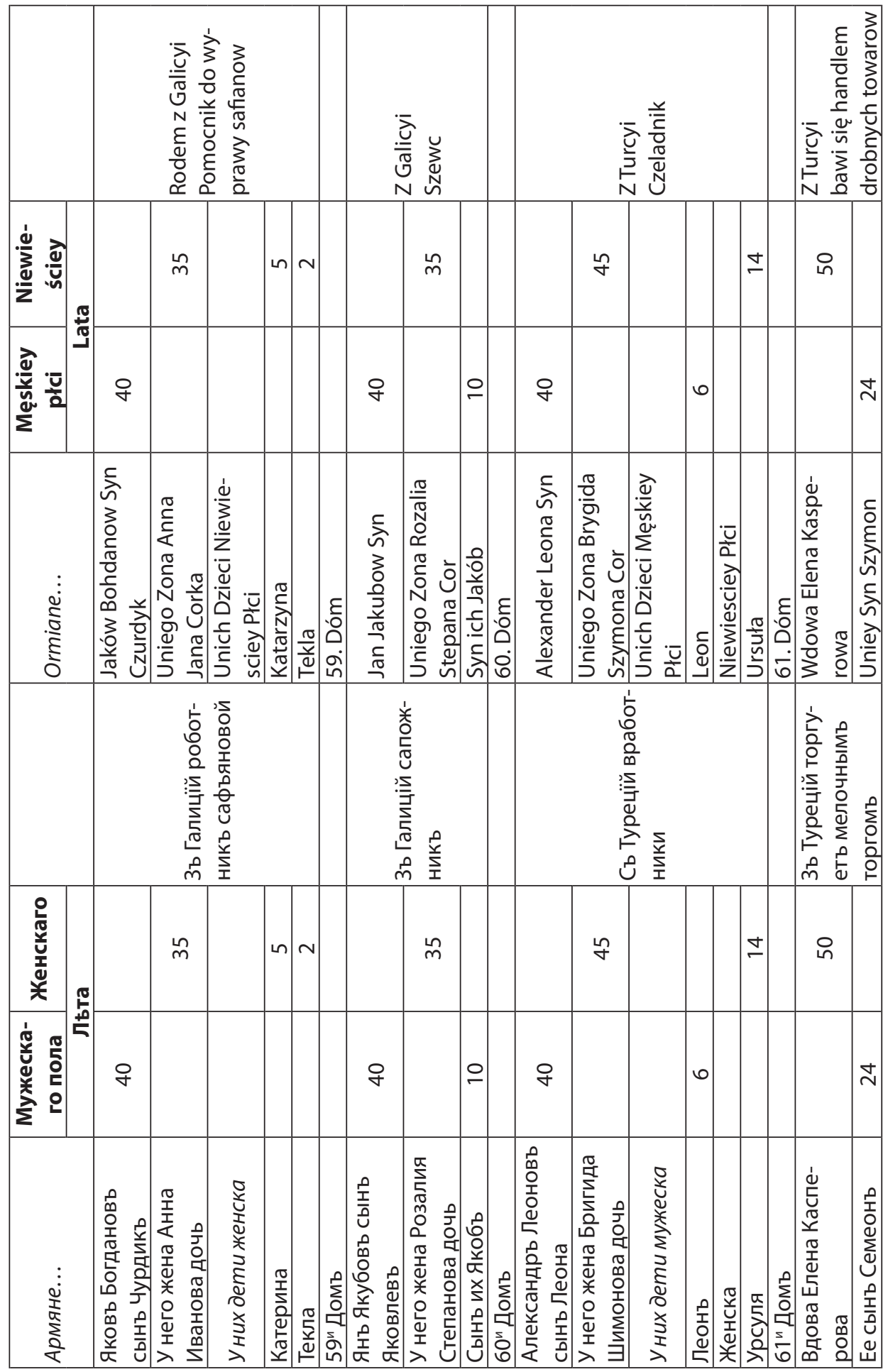




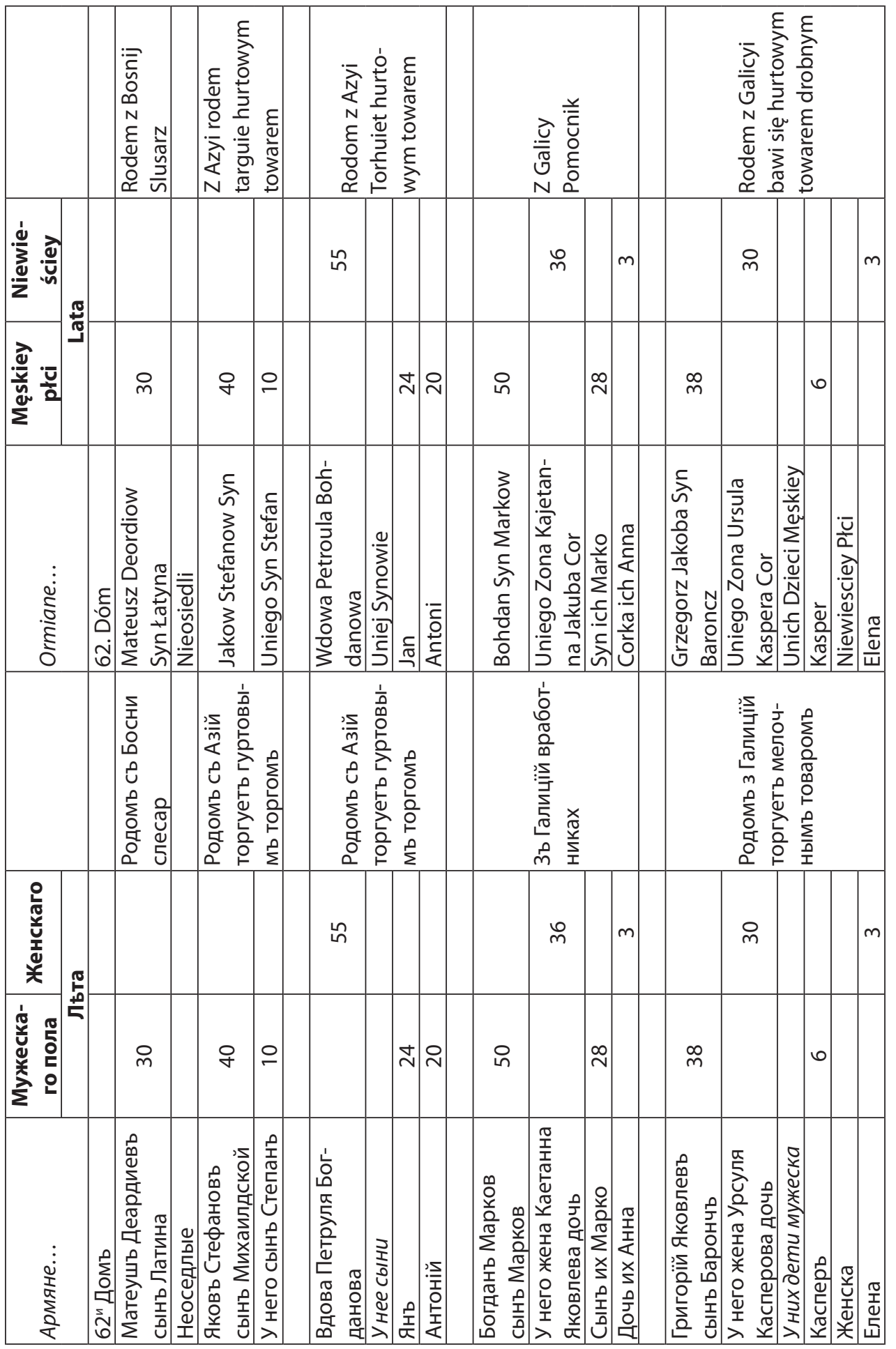




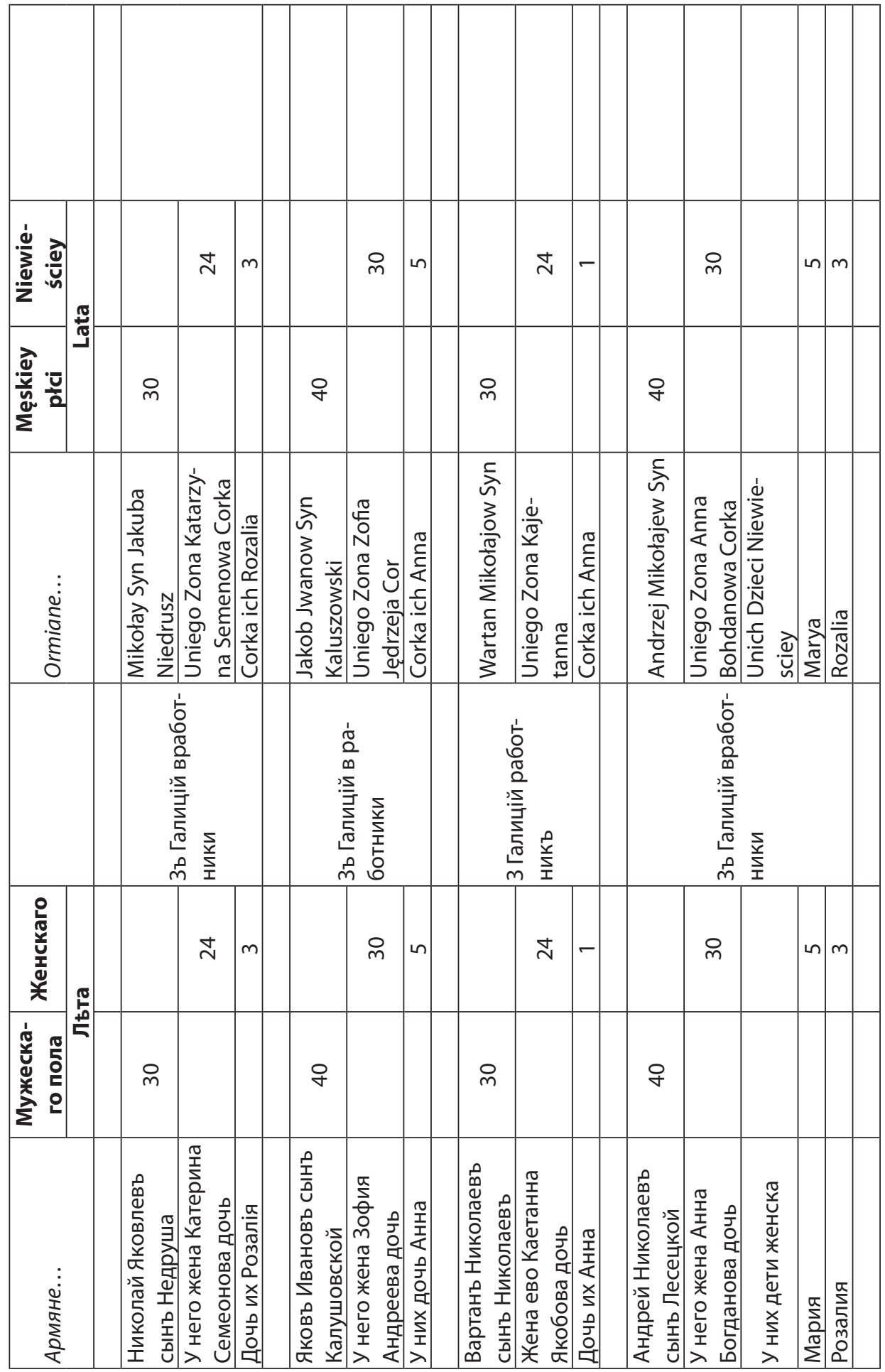




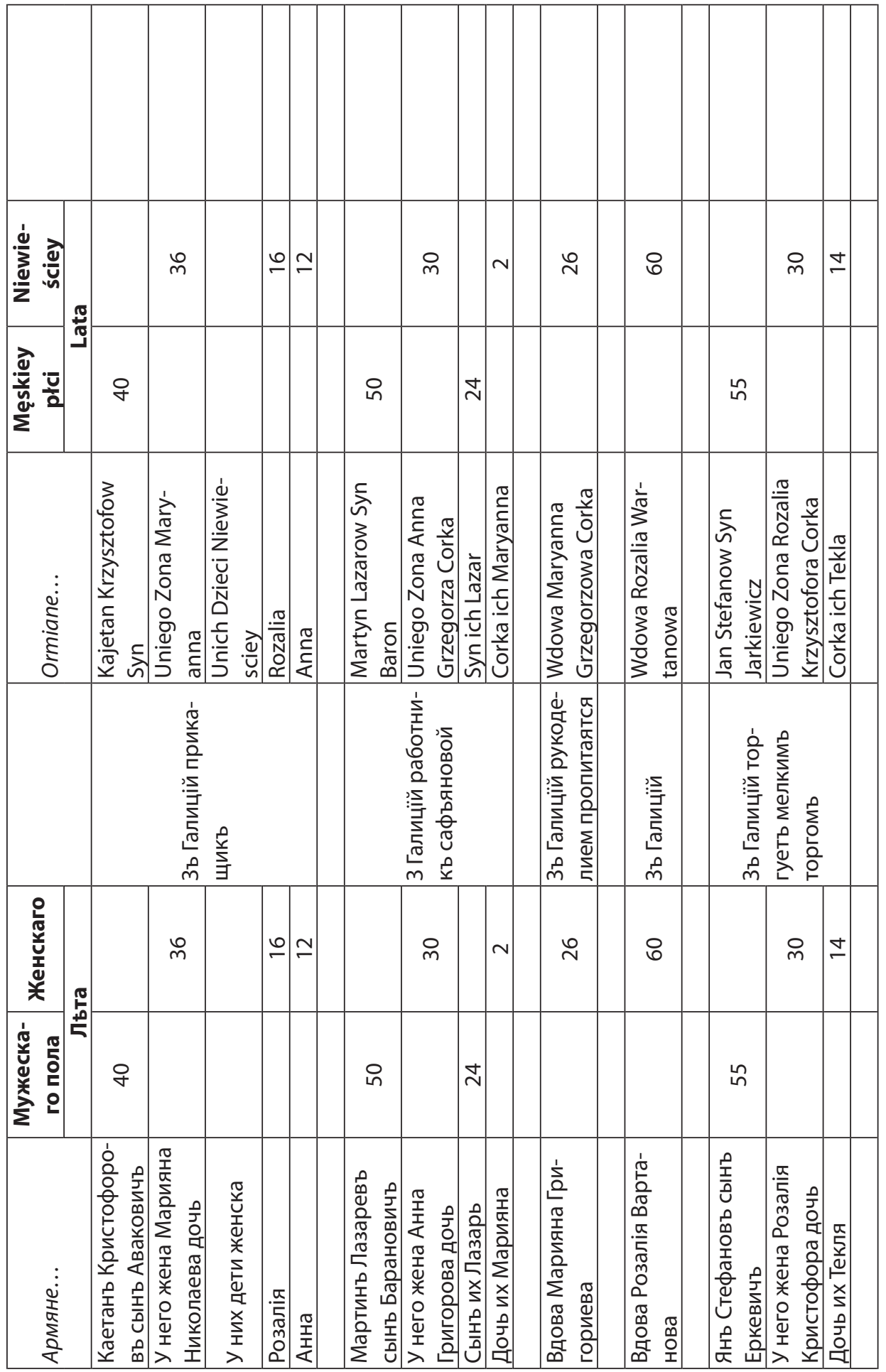




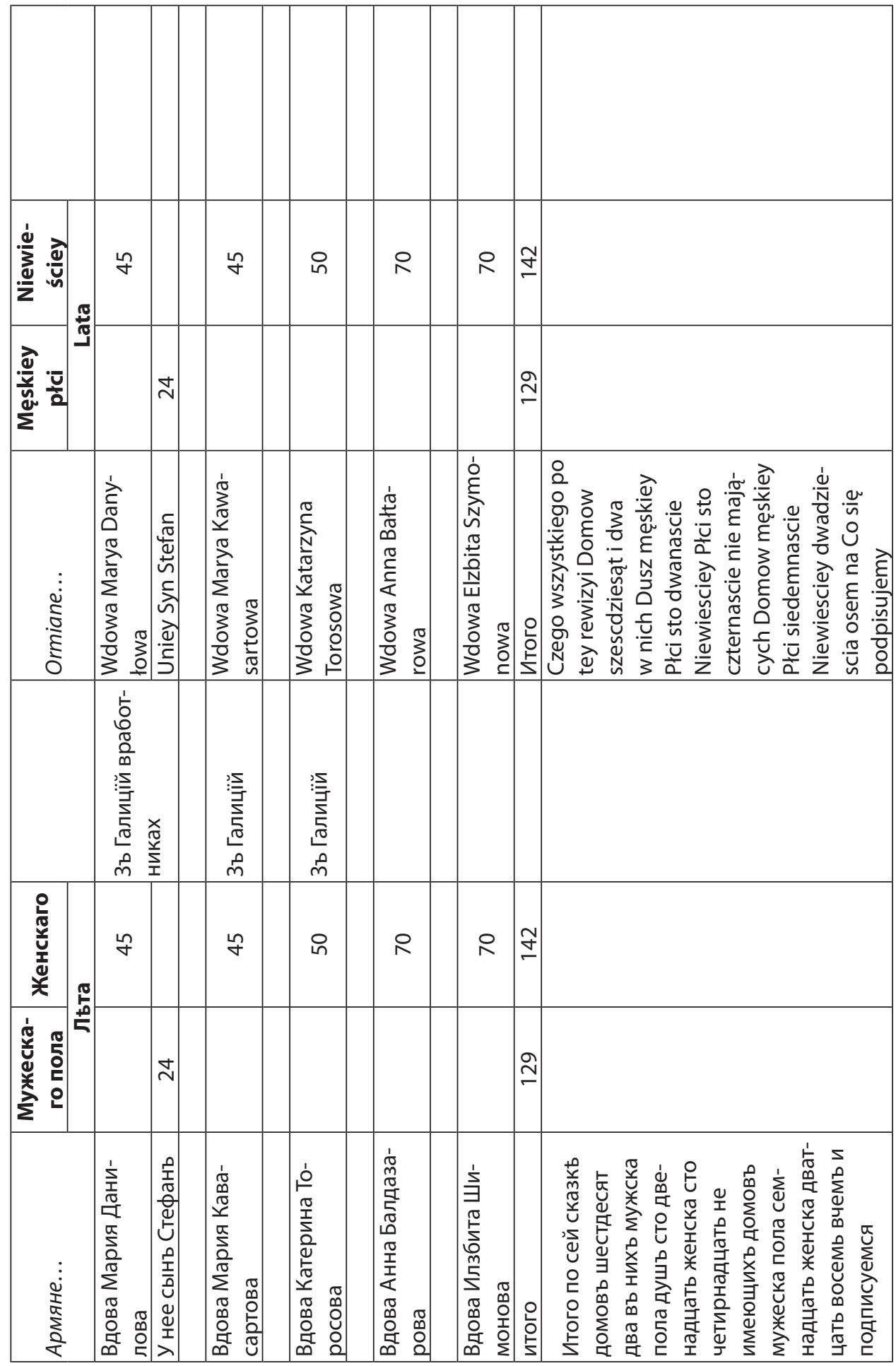




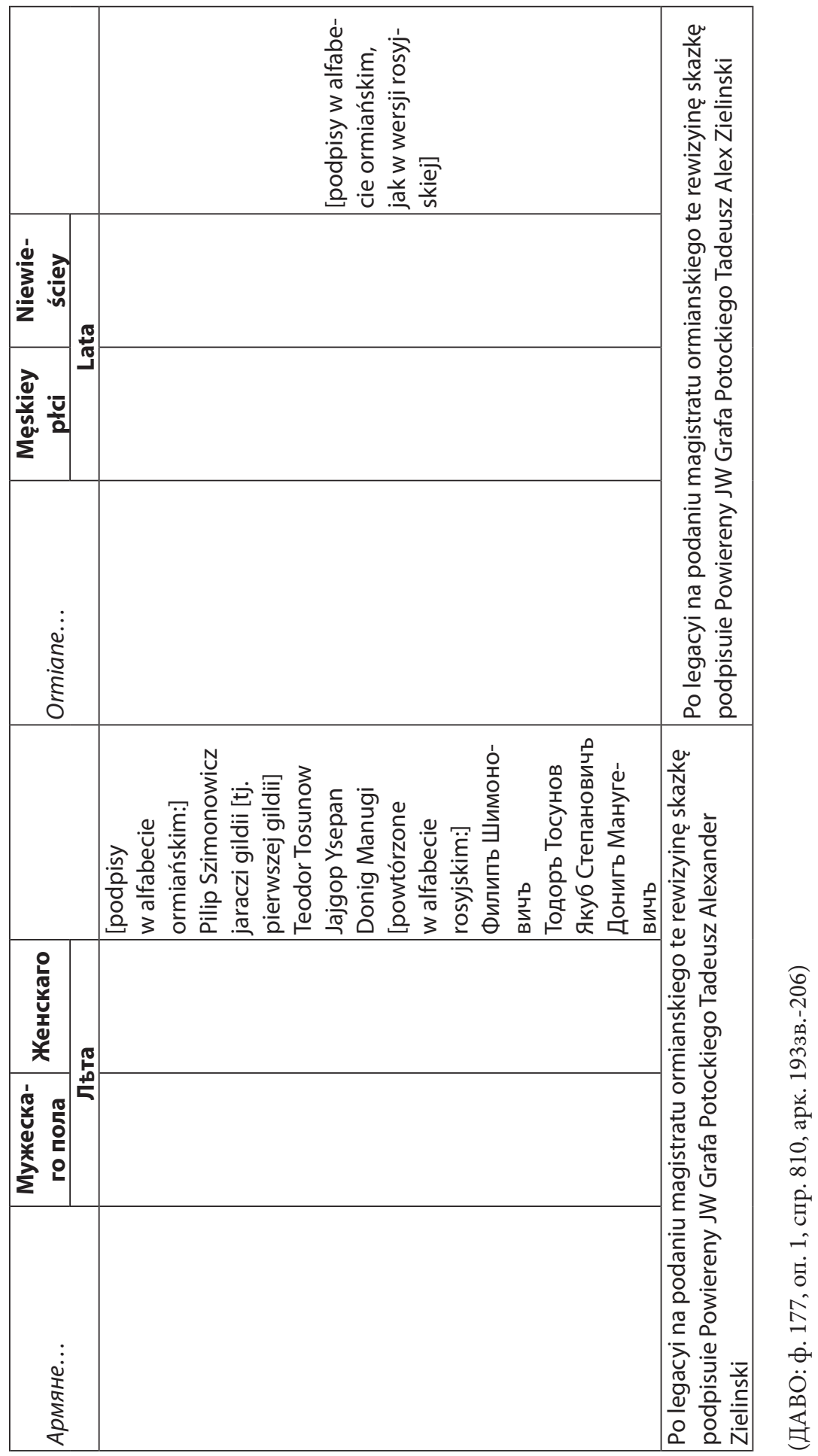




\section{Dokument 3}

\begin{tabular}{|c|c|c|c|}
\hline \multirow[b]{2}{*}{ № } & \multirow[b]{2}{*}{$\begin{array}{c}\text { Вьдомость Найденныхъ незаписанныхъ въ } \\
\text { Ревизію въ городь Могилевь армянъ }\end{array}$} & \multicolumn{2}{|c|}{ Льта } \\
\hline & & \begin{tabular}{|c|}
$\begin{array}{c}\text { Мужескаго } \\
\text { пола }\end{array}$ \\
\end{tabular} & Женскаго \\
\hline & А йменно & & \\
\hline 1 & в Антона дочь Магдалина ${ }^{14}$ & & 2 \\
\hline 4 & в Гаврила жена Анна Исакова & & 21 \\
\hline & $\begin{array}{l}\text { Ребекка Криштофова } \\
\text { дочь ее Катерина Криштофова }\end{array}$ & & $\begin{array}{l}46 \\
15\end{array}$ \\
\hline & $\begin{array}{l}\text { в Петрунели Бунетовой прикащикъ Вартанъ } \\
\text { Заворияшовичъ }{ }^{15}\end{array}$ & 14 & \\
\hline 5 & в Каетана приемушъ Вицентій ${ }^{16}$ & 7 & \\
\hline 9 & $\begin{array}{l}\text { В Данилы дочери } \\
\text { Варвара } \\
\text { Мария }^{17}\end{array}$ & & $\begin{array}{l}4 \\
2\end{array}$ \\
\hline & $\begin{array}{l}\text { Сестра Давыдова Мария Туманова } \\
\text { в ней дочери } \\
\text { Катерина } \\
\text { Анна } \\
\end{array}$ & & $\begin{array}{l}41 \\
17 \\
12\end{array}$ \\
\hline 8 & $\begin{array}{l}\text { в Богдана дочери } \\
\text { Анна } \\
\text { Елжбета } \\
\text { Катерина }{ }^{18} \\
\end{array}$ & & $\begin{array}{l}15 \\
13 \\
12\end{array}$ \\
\hline 40 & в Каетана мать Мария Якова & & 48 \\
\hline 11 & в Каспера сын Богданъ ${ }^{19}$ & 4 & \\
\hline & Мария Дмитриева вдова ${ }^{20}$ & & 43 \\
\hline & $\begin{array}{l}\text { Каетан Криштофоровъ } \\
\text { Жена его Мария Григоріева } \\
\text { у них дочери } \\
\text { Рузалія } \\
\text { Егонна } 21\end{array}$ & 45 & $\begin{array}{l}48 \\
17 \\
13\end{array}$ \\
\hline & $\begin{array}{l}\text { Анастасия Петрова вдова } \\
\text { мать ее Еертимія Васильева } 22\end{array}$ & & $\begin{array}{l}43 \\
91\end{array}$ \\
\hline & коморник Яленецъ ${ }^{23}$ & 70 & \\
\hline
\end{tabular}

14 Późniejsza notatka: „Не писать”.

15 Późniejsza notatka: „Изъ кардона куда и пошель”.

16 Późniejsza notatka: „Записан въ [...] а также былъ навремя”.

17 Późniejsza notatka dotycząca obu wymienionych wyżej imion: „Посль ревизіи”.

18 Późniejsza notatka dotycząca trzech wymienionych wyżej imion: „Сіи написаны излишне другими именами под № $8^{\text {м’. }}$

19 Późniejsza notatka, przekreślona: „не писать ибо после ревизіи”.

20 Późniejsza notatka: „не изъ армянъ”.

${ }^{21}$ Późniejsza notatka dotycząca czterech wymienionych wyżej imion: „вдвойне подъ №40"

${ }^{22}$ Późniejsza notatka dotycząca obu wymienionych wyżej imion: „не из армянъ”.

23 Późniejsza notatka: „небыло и нетъ и почему записанъ неизвестно”. 


\begin{tabular}{|c|c|c|c|}
\hline \multirow[b]{2}{*}{ № } & \multirow{2}{*}{$\begin{array}{c}\text { Вьдомость Найденныхъ незаписанныхъ въ } \\
\text { Ревизію въ городь Могилевь армянъ }\end{array}$} & \multicolumn{2}{|c|}{ Льта } \\
\hline & & $\begin{array}{c}\text { Мужескаго } \\
\text { пола }\end{array}$ & Женскаго \\
\hline 10 & в Доминікова сына Самуеля жена Анна Михайлова & & 15 \\
\hline 17 & $\begin{array}{l}\text { в Тодора сынъ Богданъ } \\
\text { мать его Рузалія Шереметева }\end{array}$ & 21 & 72 \\
\hline 61 & $\begin{array}{l}\text { въ вдовы Елены невестка } \\
\text { Кашкарова } 25 \\
\text { у нье дочь Елена }{ }^{26}\end{array}$ & & $\begin{array}{c}29 \\
3\end{array}$ \\
\hline 16 & в Николаева сына Амбросія сынъ Николай & 3 & \\
\hline & Николай Васильевъ [сынъ] Поповичъ изъ Ру[...] & 5[?] & \\
\hline 19 & в Григория братъ Доминикъ & 17 & \\
\hline 28 & в Якова дочь Катерина 27 & & 3 \\
\hline 26 & в Богдана дочь Текла²8 & & 2 \\
\hline 22 & $\begin{array}{l}\text { в Мегердича коморница } \\
\text { Каетана Асвадерова } \\
\text { у нье дочь Мариянна }\end{array}$ & & $\begin{array}{l}30 \\
12\end{array}$ \\
\hline 25 & в Доменника мать Урсуля & & 94 \\
\hline 30 & $\begin{array}{l}\text { в Якова швагеръ Иванъ Маркевичъ } \\
\text { родственница ихъ Мария Самоиликова }{ }^{29}\end{array}$ & 30 & 86 \\
\hline & вдовы Маріи дочь Текла & & 14 \\
\hline 33 & $\begin{array}{l}\text { в Якова сынъ Кавасардъ } \\
\text { мать ево София Давыдова }{ }^{31}\end{array}$ & 16 & 58 \\
\hline 36 & в Григория мать Елжбета Доминикова вдова ${ }^{32}$ & & 85 \\
\hline & $\begin{array}{l}\text { Тодоръ Игнатовъ Глатковскій } \\
\text { жена ево Анна Иванова } \\
\text { у них дочь Анастасія }{ }^{33}\end{array}$ & 30 & $\begin{array}{c}20 \\
1\end{array}$ \\
\hline & $\begin{array}{l}\text { Богданъ Яковлевъ сынъ Барончовъ } \\
\text { жена ево Урсуля Якубова } \\
\text { у нихъ сынъ Якубъ }\end{array}$ & $\begin{array}{c}36 \\
5\end{array}$ & 26 \\
\hline 51 & в Григорія дочь Анна & & 15 \\
\hline 37 & $\begin{array}{l}\text { в Якова невестка Мария Григориева } \\
\text { у нье сынъ Еремей Криштофоровъ }\end{array}$ & 7 & 2[?] \\
\hline 50 & в Каетана дочь Анна ${ }^{35}$ & & 2 \\
\hline
\end{tabular}

${ }^{24}$ Późniejsza notatka: „не его а шляхетскій [...]”.

25 Późniejsza notatka: „написана ошибкой ибо донынъ холость”.

26 Późniejsza notatka: „неиме неписать”.

27 Późniejsza notatka: „посль ревизіи”.

28 Późniejsza notatka: „посль ревизіи”.

29 Późniejsza notatka: „съ кардона”.

30 Późniejsza notatka: „съ кардона”.

31 Późniejsza notatka: „не была”.

32 Późniejsza notatka: „не была”.

33 Późniejsza notatka: „посль ревизіи”.

34 Późniejsza notatka: „вдвойне [...]”.

35 Późniejsza notatka: „посль ревизіи”. 


\begin{tabular}{|c|c|c|c|}
\hline \multirow[b]{2}{*}{ № } & \multirow[b]{2}{*}{$\begin{array}{c}\text { Вьдомость Найденныхъ незаписанныхъ въ } \\
\text { Ревизію въ городь Могилевь армянъ }\end{array}$} & \multicolumn{2}{|c|}{ Льта } \\
\hline & & $\begin{array}{c}\begin{array}{c}\text { Мужескаго } \\
\text { пола }\end{array} \\
\end{array}$ & Женскаго \\
\hline 41 & В Томаша сынъ Шимонъ & 18 & \\
\hline & Въ вдовы Катерины сынъ Амбросій & 21 & \\
\hline 23 & в Арутина мать Забеля ${ }^{36}$ & & 72 \\
\hline 14 & $\begin{array}{l}\text { у Ивана невестка Марияна Богданова } \\
\text { братъ ево Николай Богдановъ }\end{array}$ & 20 & 18 \\
\hline 60 & $\begin{array}{l}\text { в Александра коморникъ } \\
\text { Иван Адьтиневичъ } \\
\text { жена ево Анна Александрова } \\
\text { у нихъ дочери } \\
\text { Мария } \\
\text { Рузалія }{ }^{37}\end{array}$ & 60 & $\begin{array}{l}29 \\
3 \\
2\end{array}$ \\
\hline 57 & $\begin{array}{l}\text { в Якова коморникъ } \\
\text { Мегерддачъ } \\
\text { жена ево Улияна Яковлева }\end{array}$ & 39 & 34 \\
\hline 53 & в Криштофа мать Анна Томашова & & 74 \\
\hline 52 & $\begin{array}{l}\text { в Луки Яковой жены сестра Мария Вартанова вдова } \\
\text { у нье дочери } \\
\text { Гарабеима } \\
\text { Кася }\end{array}$ & & $\begin{array}{l}35 \\
12 \\
10\end{array}$ \\
\hline 62 & $\begin{array}{l}\text { в Матеуша братъ Михаило } \\
\text { мать ево Рузалия }\end{array}$ & & \\
\hline & $\begin{array}{l}\text { Антоньи Григоріевъ } \\
\text { племянники ево } \\
\text { Каетанъ } \\
\text { Доминикъ } \\
\text { Антонъ Исаковъ }{ }^{39}\end{array}$ & $\begin{array}{c}37 \\
8 \\
12 \\
14\end{array}$ & \\
\hline 47 & в Стефана Иванова Невестка Анна Иванова ${ }^{40}$ & & 27 \\
\hline & Антон Араканъ ${ }^{41}$ & 61 & \\
\hline & Киворкъ Киворкъ Лусагановъ ${ }^{42}$ & 42 & \\
\hline & Итого & 26 & 50 \\
\hline
\end{tabular}

(ДАВО, ф. 177, оп. 1, спр. 810, арк. 207).

36 Późniejsza notatka: „съ кардона”.

37 Późniejsza notatka, dotycząca obu wymienionych wyżej imion: „Посль ревизіи”.

38 Późniejsza notatka: „Нет небыло”.

39 Późniejsza notatka, dotycząca obu wymienionych wyżej imion: „работники”.

40 Późniejsza notatka: „нетъ и небыло и почему напис [...]”.

41 Późniejsza notatka: „нетъ”.

42 Późniejsza notatka: „записанъ въ [...]”. 


\section{Dokument 4}

\begin{tabular}{|c|c|c|c|c|}
\hline \multirow{3}{*}{ № } & \multicolumn{4}{|c|}{$\begin{array}{c}\text { Вьдомость } \\
\text { Города Могилева находящимся армянамъ }\end{array}$} \\
\hline & \multirow[b]{2}{*}{ А именно } & \multicolumn{2}{|c|}{\begin{tabular}{|c|} 
Льта \\
\end{tabular}} & \multirow[b]{2}{*}{ Показаніе } \\
\hline & & $\begin{array}{c}\text { Мужескаго } \\
\text { пола }\end{array}$ & Женскаго & \\
\hline 5 & $\begin{array}{l}\text { В Каетана дочь } \\
\text { (Гаракелиа?) }^{43}\end{array}$ & & 13 & Слепа на обои глаза \\
\hline 12 & $\begin{array}{l}\text { В Вартана сынъ } \\
\text { Фед[ор] }\end{array}$ & 4 & & $\begin{array}{l}\text { По ревизїй родившися а по } \\
\text { ошибки наймычкой сказана } \\
\text { но небытіемъ хозяев в доме }\end{array}$ \\
\hline 11 & В Каетана сынъ Томаш 45 & 3 & & \\
\hline & $\begin{array}{l}\text { В неоседлых в Богдана } \\
\text { сыновъя } \\
\text { Каетан }^{46} \\
\text { Куба }\end{array}$ & $\begin{array}{c}16 \\
2 \\
\end{array}$ & & $\begin{array}{l}\text { Ошибкою матери сказано } \\
\text { что есть сыны один уже } \\
6 \text { год в Цысарій } \\
\text { По ревизии родившися }\end{array}$ \\
\hline 10 & $\begin{array}{l}\text { В Доменика работник } \\
\text { Антоній Яковлев }\end{array}$ & 44 & & Находится в богаденнь \\
\hline 61 & $\begin{array}{l}\text { Во вдовы Елены внукъ } \\
\text { Каетан }^{49}\end{array}$ & 2 & & $\begin{array}{l}\text { По ошике матери сказанъ } \\
\text { что онъ [...] лет а ему } 4 \text { [...] }\end{array}$ \\
\hline
\end{tabular}

(ДАВО, ф. 177, оп. 1, спр. 810, арк. 208).

\section{Bibliografia}

\section{Źródła archiwalne}

Центральний державний історичний архів України у м. Київ: ф. 486, оп. 3, спр. 335 Державний архів Вінницької області: ф. 177, оп. 1, спр. 810

\section{Źródła drukowane}

(Wojenno-statisticzeskoje) Военно-статистическое обозрение Российской империи. Подольская губерния, 10/2, Санкт-Петербург 1849

\section{Opracowania}

(Diaczok) Дячок В., Маловідомі джерела про розселення вірмен у Подільській губернії кіния ХVIII століття, w: Актуальні питання вірменознавства, 3/4, Вінниця 2016, s. 24-39

43 Późniejsza notatka: „небыло”.

44 Późniejsza notatka: „поревизіи”.

45 Późniejsza notatka: „поревизіи”.

46 Późniejsza notatka: „не здъшній и не былъ”.

47 Późniejsza notatka: „поревизіи”.

48 Późniejsza notatka: „отслужа пошель неизвестно куда”.

49 Późniejsza notatka: „поревизіи”. 
(Lehun) Легун Ю., Петренко О., Матеріали ревізійного перепису населення 17951796 рр. у фондах Державного архіву Віннииької області, Вінниця 2005

Z języka ukraińskiego przełożył Andrzej A. Zięba

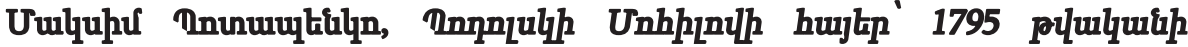

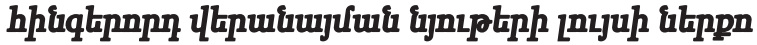

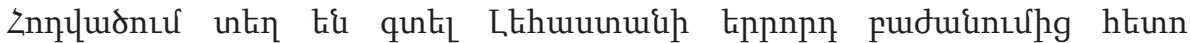

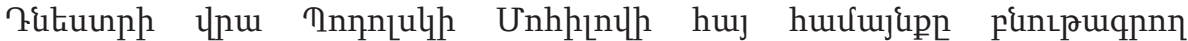

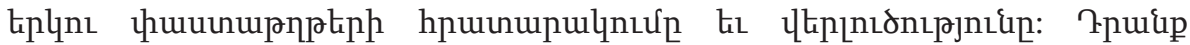

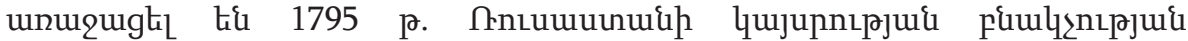

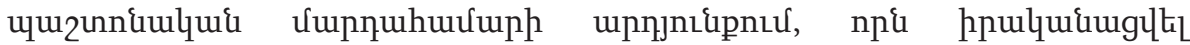

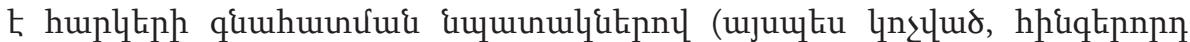

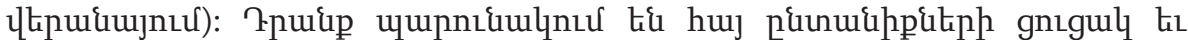

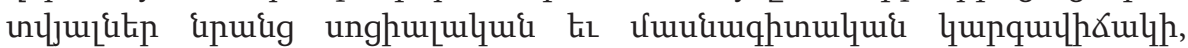

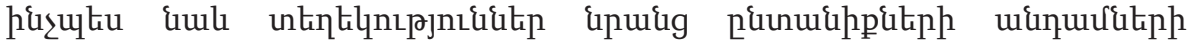

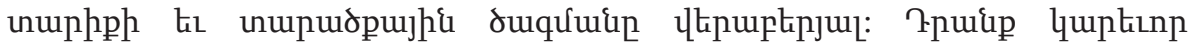

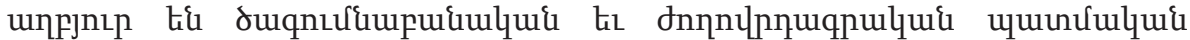
htinuqnunnıpnı\&itiph hưưup:

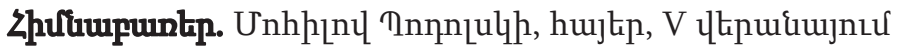

Maksym Potapenko, Armenians from Mohylów Podolski in the Light of the Documents from the Fifth Revision of 1795

The article contains an edit and analysis of two documents that describe the Armenian community in Mohylów Podolski (Mohyliv-Podilskyi) on the Dniester after the Third Partition of Poland. They were created following the 1795 census of the population of Russia which was used to levy a poll tax (the so-called fifth revision). The documents contain a list of Armenian families and data on their social and professional status, age and territorial origin. They constitute an important source of information for genealogical, demographic, and historical research.

Keywords: Mohylów Podolski, Armenians, Fifth Revision 


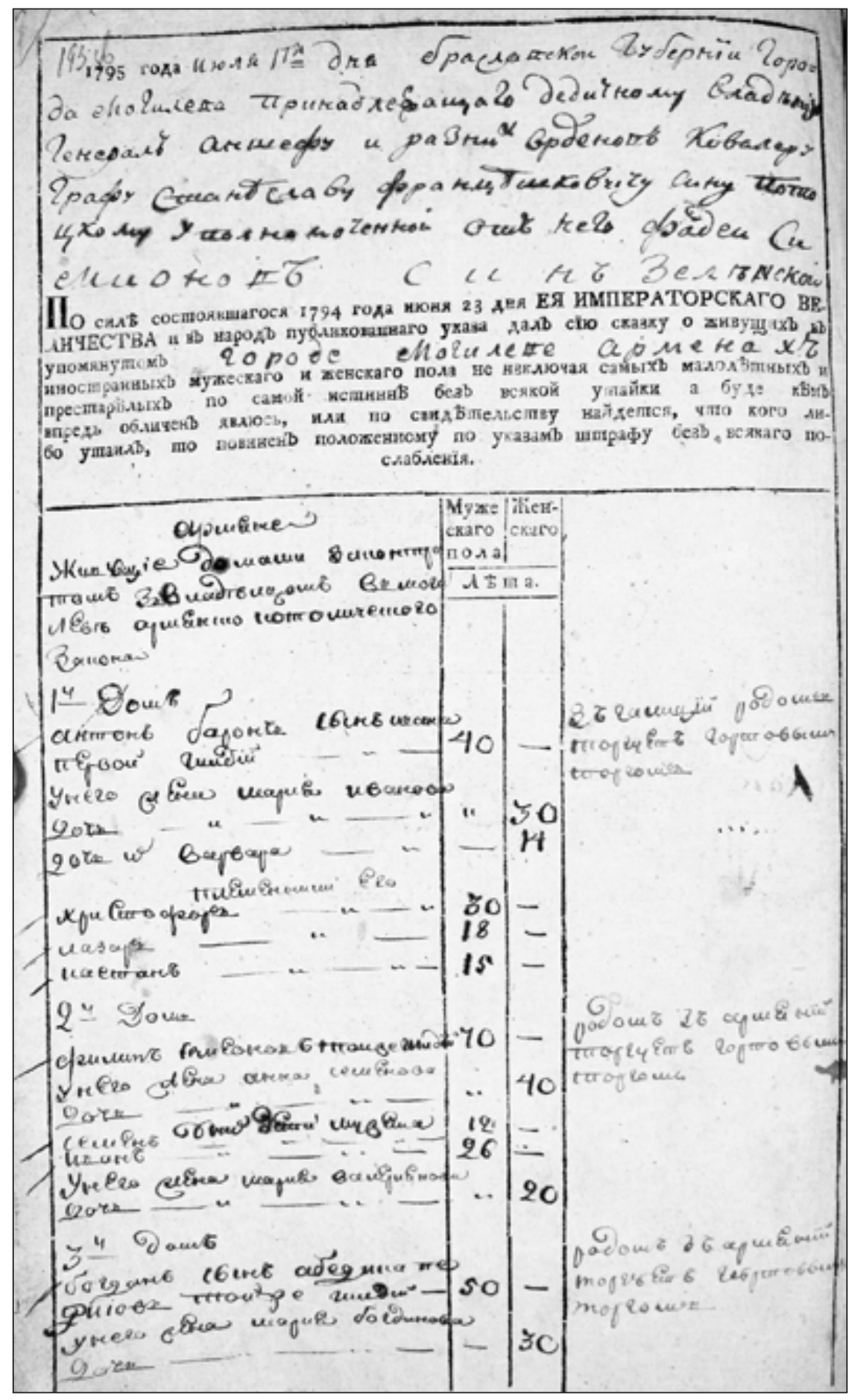

Pierwsze karty Rewizyinej wiadomości o mieszkaiących w pomienionym miescie Mohylowie Ormianach cudzoziemcach meskiej ptci i niewieściey, 17 lipca 1795 roku, Державний архів Вінницкої області, ф. 177, оп. 1, спр. 810 


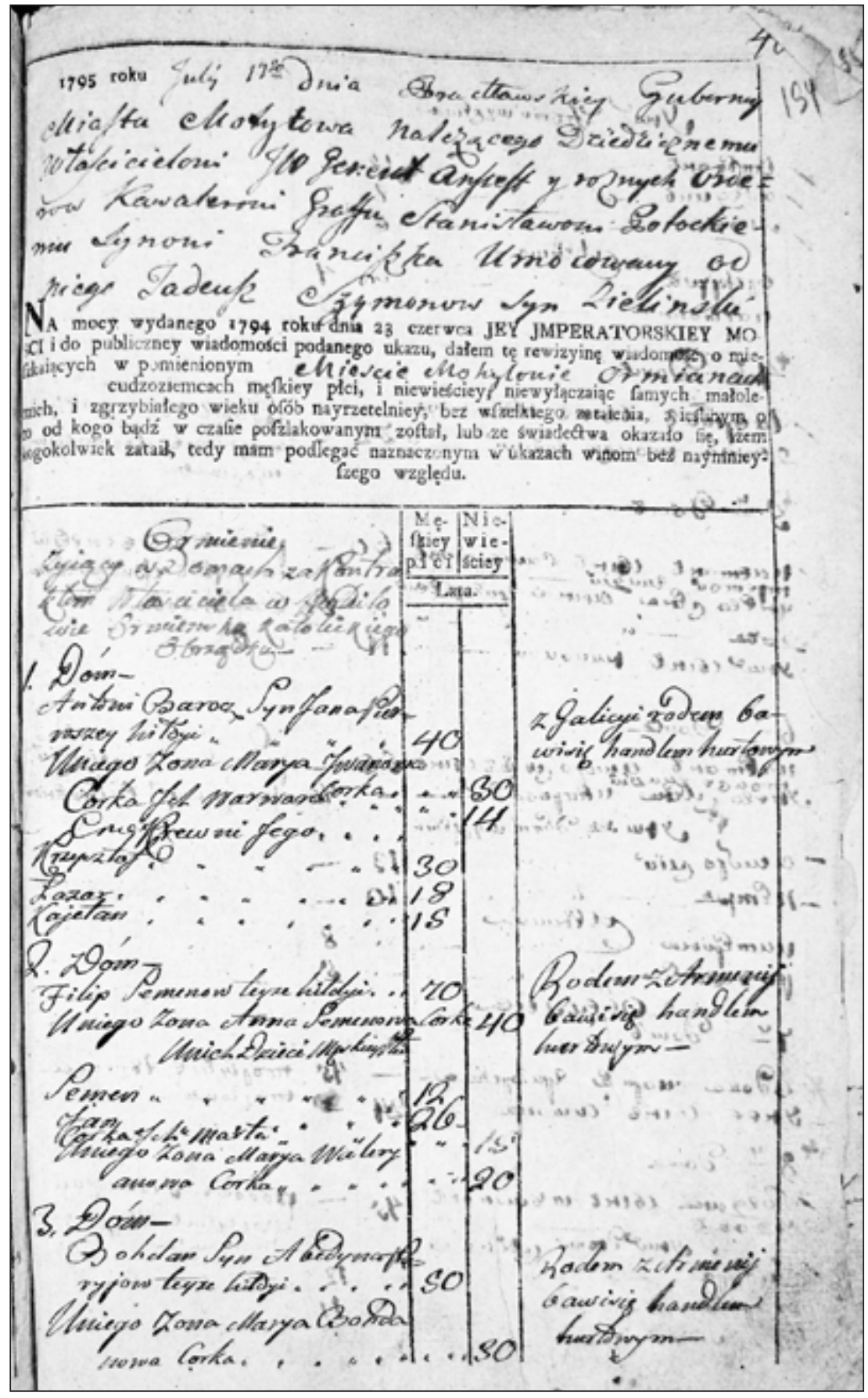

